\title{
A Spatially Explicit Suspended-Sediment Load Model for Western Oregon
}

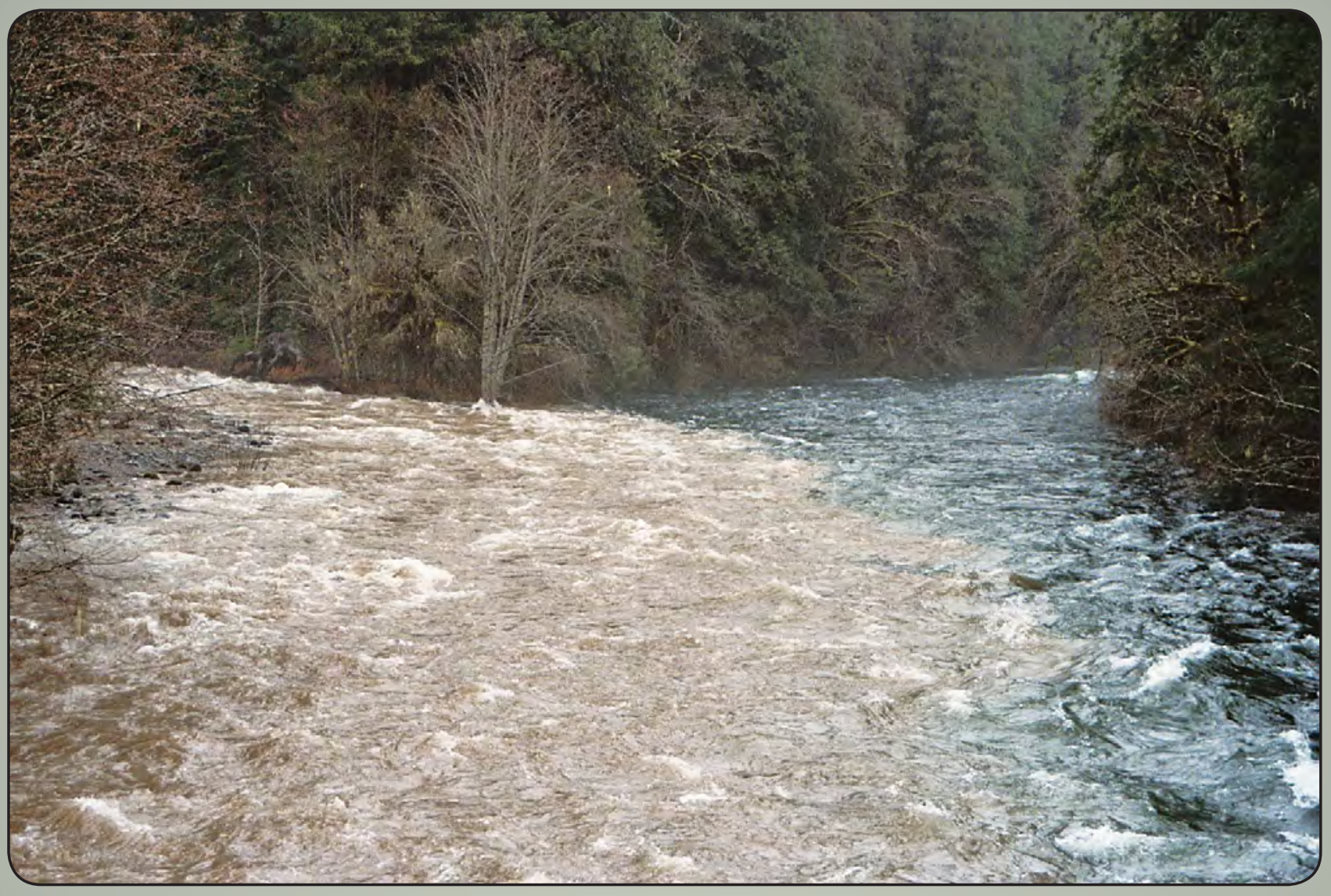

Scientific Investigations Report 2016-5079

U.S. Department of the Interior

U.S. Geological Survey 
Cover: Confluence of turbid Deer Creek and the much clearer Mackenzie River (latitude 44.239, longitude -122.058) during high flow, western Oregon. Photograph by Jim 0'Connor, U.S. Geological Survey, January 29, 2003. 


\section{A Spatially Explicit Suspended-Sediment Load Model for Western Oregon}

By Daniel R. Wise and Jim E. O'Connor

Scientific Investigations Report 2016-5079 


\title{
U.S. Department of the Interior SALLY JEWELL, Secretary
}

\section{U.S. Geological Survey Suzette M. Kimball, Director}

\author{
U.S. Geological Survey, Reston, Virginia: 2016
}

For more information on the USGS - the Federal source for science about the Earth, its natural and living resources, natural hazards, and the environment—visit http://www.usgs.gov or call 1-888-ASK-USGS.

For an overview of USGS information products, including maps, imagery, and publications, visit http://store.usgs.gov.

Any use of trade, firm, or product names is for descriptive purposes only and does not imply endorsement by the U.S. Government.

Although this information product, for the most part, is in the public domain, it also may contain copyrighted materials as noted in the text. Permission to reproduce copyrighted items must be secured from the copyright owner.

Suggested citation:

Wise, D.R., and O'Connor, J.E., 2016, A spatially explicit suspended-sediment load model for western Oregon: U.S. Geological Survey Scientific Investigations Report 2016-5079, 25 p., http://dx.doi.org/10.3133/sir20165079.

ISSN 2328-0328 (online) 


\section{Contents}

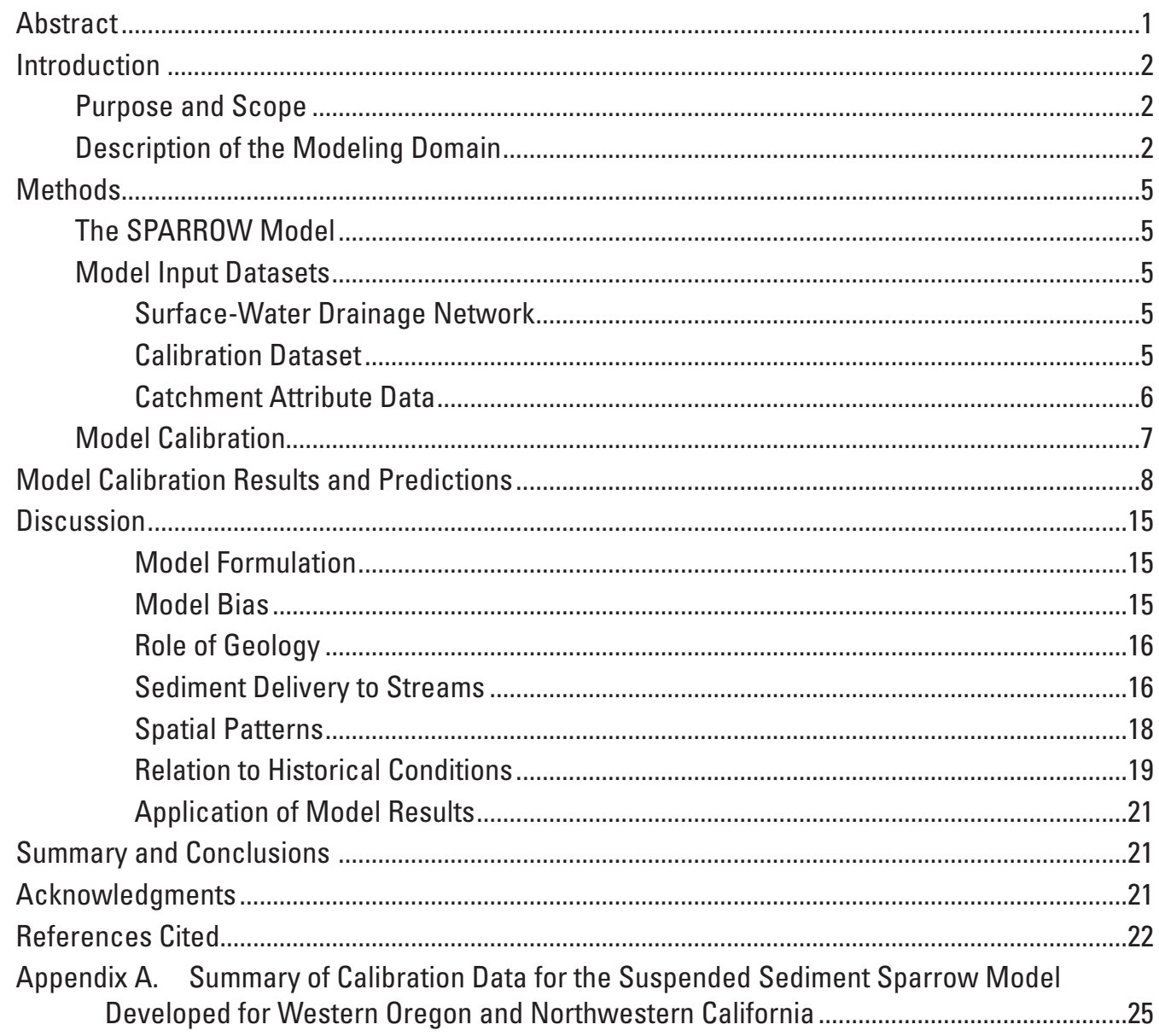




\section{Figures}

1. Map showing modeling domain for the Western Oregon SPARROW model of suspended sediment

2. Map showing mean annual precipitation and historical wildfire disturbance for western Oregon and northwestern California

3. Graph showing comparison of the measured and predicted yields from the Western Oregon SPARROW model of suspended sediment

4. Map showing studentized residuals for the Western Oregon SPARROW model of suspended sediment

5. Map showing incremental yields predicted by the Western Oregon SPARROW model of suspended sediment.

6. Map showing total instream loads within the Umpqua River Basin, Oregon, as predicted by the Western Oregon SPARROW model of suspended sediment

7. Map showing total instream loads within the Rogue River Basin, Oregon, as predicted by the Western Oregon SPARROW model of suspended sediment 14

8. Photograph showing confluence of turbid Deer Creek and the much clearer Mackenzie River during high flow on January 29, 2003, western Oregon

\section{Tables}

1. Potential explanatory variables evaluated in the Western Oregon SPARROW model.....6

2. Description of the lithologic provinces used as sources in the Western Oregon SPARROW model of suspended sediment ..........................................................................

3. Calibration results for the western Oregon SPARROW model of suspended sediment

4. Model calibration results, median incremental yields, and flow-weighted concentrations predicted for each six-digit Hydrological Unit Code watershed by the Western Oregon SPARROW model of suspended sediment.

5. Summary statistics for incremental loads predicted by the Western Oregon SPARROW model of suspended sediment

6. Comparison of historical and current estimates of suspended sediment yields for streams in western Oregon.

7. Comparison of historical and current measurements of suspended-sediment yields for streams in the Umpqua River Basin, Oregon

8. Comparison of total suspended solids, total dissolved solids, and total solids for streams in the Oregon Coast Range. 


\section{Conversion Factors}

International System of Units to Inch/pound

\begin{tabular}{|c|c|c|}
\hline Multiply & By & To obtain \\
\hline \multicolumn{3}{|c|}{ Length } \\
\hline millimeter (mm) & 0.03937 & inch (in.) \\
\hline centimeter $(\mathrm{cm})$ & 0.3937 & inch (in.) \\
\hline kilometer $(\mathrm{km})$ & 0.6214 & mile (mi) \\
\hline \multicolumn{3}{|c|}{ Area } \\
\hline square kilometer $\left(\mathrm{km}^{2}\right)$ & 247.1 & acre \\
\hline square kilometer $\left(\mathrm{km}^{2}\right)$ & 0.3861 & square mile $\left(\mathrm{mi}^{2}\right)$ \\
\hline \multicolumn{3}{|c|}{ Mass } \\
\hline metric ton (Mt) & 1.102 & short ton \\
\hline kilogram per year (kg/yr) & 2.205 & pound per year (lb/yr) \\
\hline \multicolumn{3}{|c|}{ Flow } \\
\hline cubic meter per second $\left(\mathrm{m}^{3} / \mathrm{s}\right)$ & 35.32 & cubic feet per second $\left(\mathrm{ft}^{3} / \mathrm{s}\right)$ \\
\hline centimeter per year (cm/yr) & 0.3937 & inch per year (in/yr) \\
\hline \multicolumn{3}{|c|}{ Application rate } \\
\hline $\begin{array}{l}\text { kilograms per hectare per year } \\
{[(\mathrm{kg} / \mathrm{ha}) / \mathrm{yr}]}\end{array}$ & 0.8921 & $\begin{array}{l}\text { pounds per acre per year } \\
{[(\text { lb/acre }) / y r]}\end{array}$ \\
\hline $\begin{array}{l}\text { kilograms per square kilometer per } \\
\text { year }\left[\left(\mathrm{kg} / \mathrm{km}^{2}\right) / \mathrm{yr}\right]\end{array}$ & 0.008921 & $\begin{array}{l}\text { pounds per acre per year } \\
{[(\mathrm{lb} / \mathrm{acre}) / \mathrm{yr}]}\end{array}$ \\
\hline
\end{tabular}

\section{Datum}

Horizontal coordinate information is referenced to the North American Datum of 1983 (NAD 83). 



\title{
A Spatially Explicit Suspended-Sediment Load Model for Western Oregon
}

\author{
By Daniel R. Wise and Jim E. O'Connor
}

\section{Abstract}

We calibrated the watershed model SPARROW (Spatially Referenced Regressions on Watershed attributes) to give estimates of suspended-sediment loads for western Oregon and parts of northwestern California. Estimates of suspended-sediment loads were derived from a nonlinear least squares regression that related explanatory variables representing landscape and transport conditions to measured suspended-sediment loads at 68 measurement stations. The model gives estimates of model coefficients and their uncertainty within a spatial framework defined by the National Hydrography Dataset Plus hydrologic network. The resulting model explained 64 percent of the variability in suspendedsediment yield and had a root mean squared error value of 0.737 . The predictor variables selected for the final model were (1) generalized lithologic province, (2) mean annual precipitation, and (3) burned area (by recent wildfire). Other landscape characteristics also were considered, but they were not significant predictors of sediment transport, were strongly correlated with another predictor variable, or were not as significant as the predictors selected for the final model.

The northern Oregon coastal drainages had the highest predicted suspended sediment yields (median yield 475 kilograms per hectare per year) and the Klamath River Basin had the lowest (median yield 53 kilograms per hectare per year). Quaternary deposits were, on average, the largest contributor to incremental suspended-sediment yield even though this lithologic province only makes up 17 percent of the modeling domain. Coast Range sedimentary rocks and Coast Range volcanic rocks had high suspended-sediment yields whereas, in addition to the Klamath terrane, the Western Cascade and High Cascade lithologic provinces had low suspended-sediment yields. Precipitation and the area affected by recent wildfire both positively correlated with suspendedsediment load.
Suspended-sediment transport rates predicted by this SPARROW model are less than historical (1956-73) and long-term (thousands of years) geological rates. This difference likely results, in part, from biases in the data underlying the SPARROW model, probably resulting in predicted suspended-sediment estimates that underestimate actual transport rates. However, the differences also likely owe to natural and human-caused variation in suspended-sediment yields as they respond to changes in climate, vegetation, fire frequency, and land use. In particular, decreases in mean annual suspended-sediment yields within the Umpqua River Basin since 1956-73 may owe to less intense forest harvest, passage of the Oregon Forest Practices Act of 1971, and increased emphasis in habitat protection in recent decades. Such sensitivity may have implications for the spatial and temporal distributions of aquatic and riparian habitats.

Knowledge of the regionally important patterns and factors in suspended-sediment sources and transport could support broad-scale, water-quality management objectives and priorities. Because of biases and limitations of this model, however, these results are most applicable for general comparisons and for broad areas such as large watersheds. For example, despite having similar area, precipitation, and land-use, the Umpqua River Basin generates 68 percent more suspended sediment than the Rogue River Basin, chiefly because of the large area of Coast Range sedimentary province in the Umpqua River Basin. By contrast, the Rogue River Basin contains a much larger area of Klamath terrane rocks, which produce significantly less suspended load, although recent fire disturbance (in 2002) has apparently elevated suspended sediment yields in the tributary Illinois River watershed. Fine-scaled analysis, however, will require more intensive, locally focused measurements. 


\section{Introduction}

Suspended sediment is particulate organic and inorganic matter mixed into the water column and transported by streams, rivers, and ocean currents. Suspended sediment is a natural consequence of rivers draining landscapes, particularly those that are eroding because of land use or topography. Suspended sediment in rivers also results from bank erosion and abrasion of bed material and bedrock within channels. Suspended sediment, where deposited, builds landforms and habitats in floodplains, rivers, estuaries, and beaches. High levels of suspended sediment, however, can adversely affect water quality and in-stream biota. Suspended sediment can suppress aquatic plant growth by reducing light penetration, abrade and clog fish gills, and sorb and transport compounds such as toxic chemicals and nutrients (Griffiths and others, 1978). High levels of suspended sediment also can adversely affect public water supplies (Morris and Fan, 1997).

Knowledge of suspended sediment fluxes is, therefore, important to understanding landscape evolution and river behavior, and for habitat and water-quality management. Owing to potential adverse effects on aquatic habitats, suspended sediment is often included in total maximum daily load (TMDL) assessments in Oregon (Oregon Department of Environmental Quality, 2015a). In particular, the Oregon Department of Environmental Quality lists 46 waterbodies within western Oregon and the Klamath River Basin as "water-quality limited" because of sedimentation or turbidity (Oregon Department of Environmental Quality, 2015a). To improve understanding of the key factors affecting suspended-sediment loads in western Oregon, we used the SPARROW (SPAtially Related Regressions on Watershed attributes) model in conjunction with 68 calibration stations to enable spatially explicit estimates (and their uncertainties) of mean annual suspended-sediment loads.

\section{Purpose and Scope}

This report presents the results of a modeling study to determine the primary contributing factors at broad or watershed scales to suspended-sediment loads in western
Oregon and parts of northwestern California. The objectives of the study were (1) to calibrate a suspended-sediment SPARROW model for western Oregon; (2) to use the calibrated model to estimate mean annual suspended-sediment loads and yields in monitored and unmonitored stream reaches throughout the modeling domain; and (3) to quantify the relative contribution of different suspended-sediment sources to in-stream suspended-sediment loads.

\section{Description of the Modeling Domain}

The domain for this modeling study encompasses $116,000 \mathrm{~km}^{2}$ of western Oregon (77 percent of the total area) and northwestern California (23 percent). Although the area in northwestern California was included in the modeling domain to strengthen the calibration dataset, this report focuses primarily on the results from western Oregon. The modeling domain includes the western slopes of the Cascade Range, the Coast Range, the intervening Willamette Valley, and parts of the Klamath and Siskiyou Mountains of northwestern California and southern Oregon. The modeled area is defined by the six-digit hydrologic unit code (HUC6) watersheds of the Smith and Klamath Rivers in northern California and southern Oregon, the Willamette River Basin, the northern Oregon coastal drainages, and the southern Oregon coastal drainages (Seaber and others, 1987). The dominant landcover types are forest land (61 percent) and scrub and grass land (26 percent), with smaller areas of agricultural land (8 percent) and developed land (5 percent) (Jin and others, 2013). The geology of the study area includes Paleozoic and Mesozoic rocks of the tectonically accreted Klamath terrane, Tertiary volcanic and sedimentary rocks within the Coast Range, Tertiary volcanic rocks of the Western and High Cascades which flank the young Quaternary volcanic rocks that form the modern volcanic arc of the Cascade Range, and unconsolidated Quaternary sediment (fig. 1) (O'Connor and others, 2014). Mean annual precipitation ranges widely within the modeling domain, from more than 400 centimeters per year $(\mathrm{cm} / \mathrm{yr})$ in the northern and southern Oregon coastal drainages to less than $40 \mathrm{~cm} / \mathrm{yr}$ within the Klamath River Basin (fig. 2). 


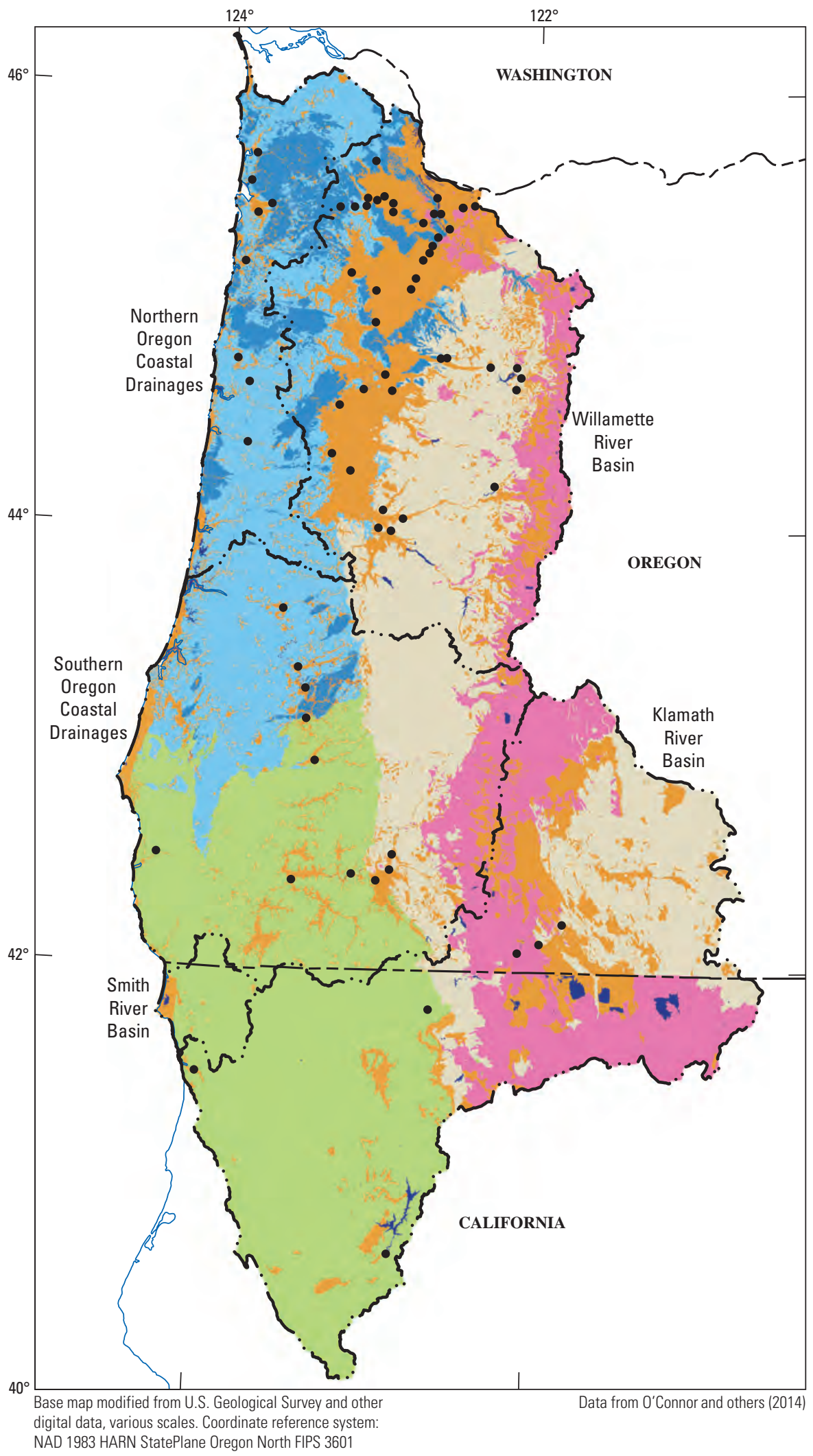

\section{EXPLANATION}

Generalized lithologic provinces Coast Range sedimentary province Coast Range volcanic province Klamath Terrane High Cascades province Western Cascades province Quaternary deposits Open water

Basin boundary

- Model calibration stations

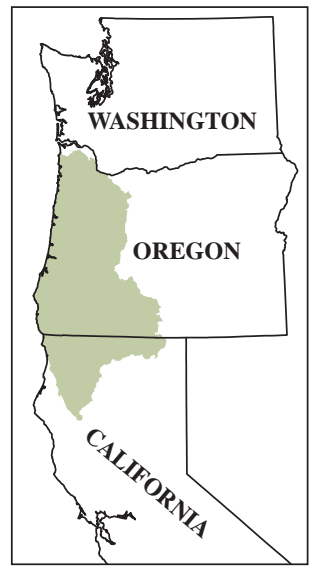

Figure 1. Modeling domain for the Western Oregon SPARROW model of suspended sediment. 


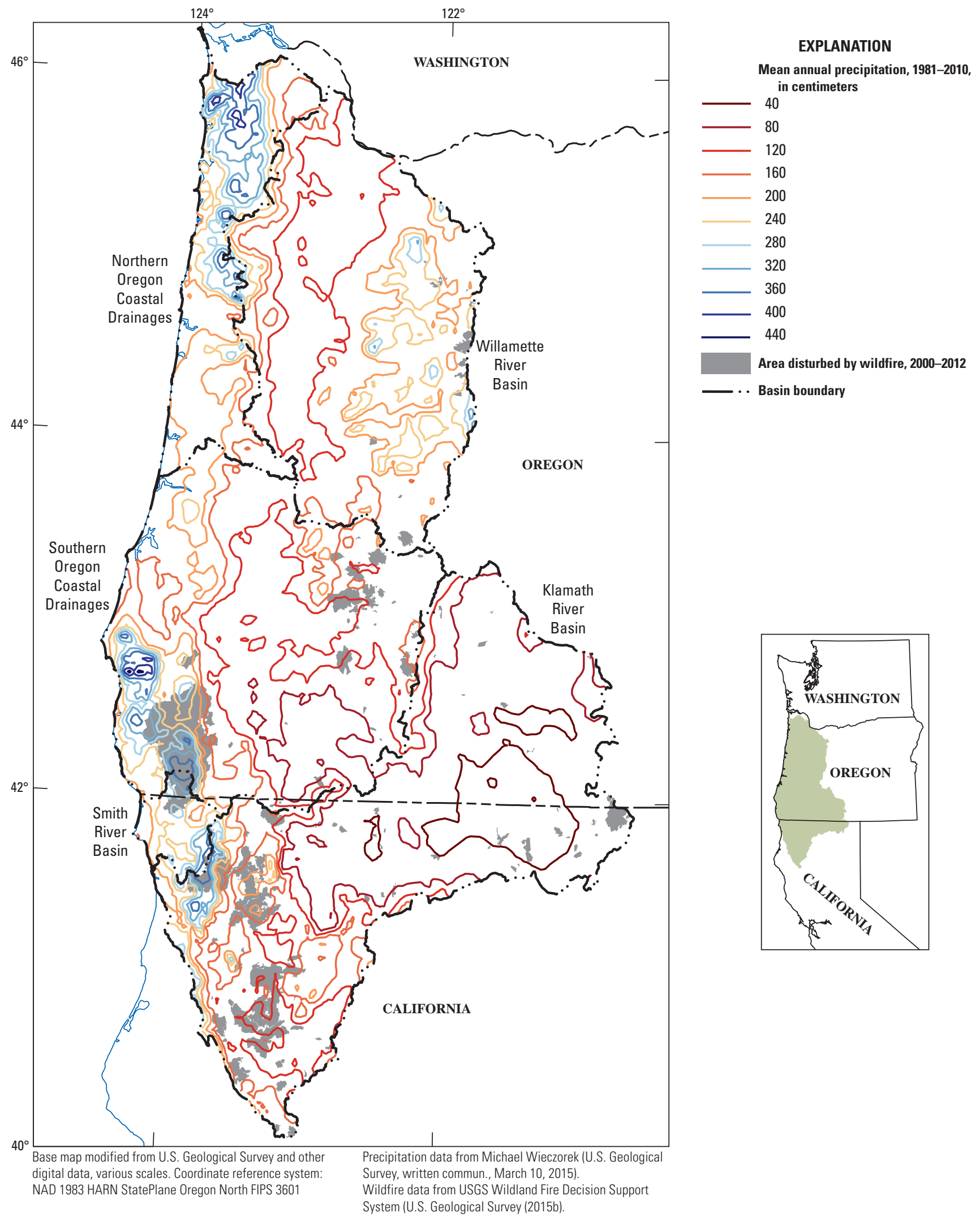

Figure 2. Mean annual precipitation and historical wildfire disturbance for western Oregon and northwestern California. 


\section{Methods}

\section{The SPARROW Model}

The SPARROW model is a hybrid statistical and mechanistic model for estimating the load of transported constituents (such as suspended sediment) through stream networks under long-term, steady-state conditions (Schwarz and others, 2006; Preston and others, 2009). The model uses a non-linear least squares regression to empirically relate catchment and water body attributes (the explanatory variables) to measured loads (the calibration dataset) within a spatially explicit framework defined by a surface-water drainage network. Suspended-sediment loss in free-flowing streams is estimated using a first-order decay process that is a function of the time of travel for each reach. Suspendedsediment loss in impoundments is estimated using an apparent settling velocity expressed in units of length per time.

A calibrated SPARROW model can predict water-quality attributes (and their uncertainties) throughout a surface-water network, including areas where no water-quality data exists. Such models have estimated nitrogen and phosphorus transport at the national level (Smith and others, 1997; Elliott and others, 2005), within large hydrologic regions (Alexander and others, 2008; Brown and others, 2011; Garcia and others, 2011; Hoos and others, 2009; Moore and others, 2011; Rebich and others, 2011; Robertson and Saad, 2011; and Wise and Johnson, 2013), and at the watershed scale (Ator and others, 2011; Johnson and others, 2013). However, there have only been two applications for suspended sediment - one for the Chesapeake Bay watershed (Brakebill, and others, 2010) and one for the continental United States (Schwarz, 2008). The application of SPARROW reported here focuses specifically on suspended-sediment transport within western Oregon and northwestern California.

\section{Model Input Datasets}

A SPARROW model requires three types of data: a surface-water drainage network, a set of calibration data, and catchment attribute data.

\section{Surface-Water Drainage Network}

The National Hydrography Dataset (NHD Plus Version 2; Horizon Systems, 2013) defined the surface-water drainage network in the model developed for this study, which we refer to as the Western Oregon SPARROW model. This vector dataset comprehensively depicts and categorizes surface-water features such as lakes, ponds, streams, and rivers (Simley and Carswell, 2009) and closely corresponds to features on 1:100,000 scale U.S. Geological Survey (USGS) topographic maps. The hydrography data within the domain of the Western Oregon SPARROW model consisted of 34,734 stream reaches, each of which starts at a point of channel initiation or tributary junction. The streams ranged from small, intermittent streams to large rivers, such as the Willamette River with a mean annual streamflow of $940 \mathrm{~m}^{3} / \mathrm{s}$ near its confluence with the Columbia River (U.S. Geological Survey, 2015a). An incremental catchment is defined for each reach within the NHD Plus Version 2 dataset, and it includes the area that drains directly to that reach (and not to upstream or downstream reaches). Most reaches defined in the hydrography data represent streams, impoundments, or coastlines, but some represent closed basins, which do not have a surface water connection to other reaches. The Western Oregon SPARROW model retained reaches representing streams, inland water bodies, and coastlines, but not reaches representing closed basins (because sediment generated in such reaches does not enter the broader hydrologic network).

Irrigation canals divert water from streams and reservoirs in some area of western Oregon and northwestern California. The Western Oregon SPARROW model included a reach attribute accounting for these diversions of streamflow by estimating the fraction of streamflow and, therefore, suspended-sediment load delivered from one reach to the reach immediately downstream. These estimates of local irrigation diversions were based on measurements of longterm average discharge. The Western Oregon SPARROW model did not explicitly account for suspended-sediment load removed by irrigation diversions and eventually returned back to streams in irrigation return flow that also could include additional sediment from local runoff. The surface-water drainage network used for the Western Oregon SPARROW model, however, did include many of these agricultural returns.

\section{Calibration Dataset}

The Western Oregon SPARROW model relied on 68 suspended sediment calibration stations distributed throughout the model domain (fig. 1; appendix A). These stations were operated by the USGS, two state agencies, two local agencies, and one university research center. The data for the USGS stations were obtained from the National Water Information System (U.S. Geological Survey, 2015a). The data for the California Department of Water Resources stations were obtained from that agency's online Data Library (California Department of Water Resources, 2015), the data for the Oregon Department of Environmental Quality stations were obtained from that agency's Laboratory Analytical Storage and Retrieval (LASAR) Web Application (Oregon Department of Environmental Quality, 2015b), and the data for the Andrews Experimental Forest station were obtained from that organization's online data catalogue (Andrews Experimental Forest, 2015). The data for the Clean Water Services station and the city of Portland, Oregon, stations were obtained directly from those agencies (Steven Anderson, Clean Water Services, written commun., June 2014; Peter Abrams, Portland Bureau of Environmental Services, written commun., May 2014). 
Selected calibration stations were those close to a streamflow-gaging station (the drainage areas for the calibration station and streamflow-gaging station were within 25 percent of each other) and had at least 23 suspendedsediment measurements between water years 1992 and 2012, with at least three samples collected during each season of measurement record. The streamflow -gaging stations were operated by either the USGS (U.S. Geological Survey, 2015a) or the Oregon Water Resources Department (Oregon Water Resources Department, 2015). All but one of the calibration stations had suspended-sediment measurements that spanned at least 5 years (one calibration station's record was a few day short of 5 years). Mean annual suspended-sediment loads for each of these stations were estimated using the USGS Fluxmaster program, which combines long-term streamflow and sediment data to produce a detrended value for a specified base year, normalized to average hydrologic conditions (Schwarz and others, 2006). This approach accounts for differences in measurement record lengths and timing, long-term trends, as well as peculiarities of hydrologic conditions during any specific year (Preston and others, 2009). For this application of the USGS Fluxmaster program, we used streamflow measured between water years 1983 and 2012 to estimate detrended annual suspended-sediment loads for water year 2012 that were normalized for average hydrologic conditions for water years 1983-2012.

The Western Oregon SPARROW model relied on measurements of suspended sediment for its calibration dataset. These measurements were based on two different methods: (1) the standard suspended-sediment method, which was used at 11 calibration stations and (2) the total suspended solids (TSS) method used at the 57 other calibration stations. Standard suspended-sediment concentration is the mass of all the sediment within a known volume of a water-sediment mixture collected directly from a water body (Guy, 1969).
In contrast, TSS is the mass of suspended material within a subsample of a water-sediment mixture collected directly from a water body. Such subsampling introduces negative bias and more variability, especially when the percentage of sand-size sediment is high (because of sediment settling before subsampling; Gray and others, 2000). Values determined by both methods are generally not used interchangeably (Gray and others, 2000), but the 11 calibration stations where standard suspended sediment was measured were not sufficient for satisfactory model development. The bias resulting from using both types of measurements was evaluated and is discussed in section, "Model Bias."

\section{Catchment Attribute Data}

Catchment attributes served as explanatory variables for predicting the measured suspended-sediment loads to formulate the Western Oregon SPARROW model. Potential explanatory variables in SPARROW model applications span a wide range of landscape and network attributes, depending on available information and factors thought important for predicting constituent loads. To enable broad and consistent SPARROW modeling efforts, many landscape properties have been compiled by the National Water-Quality Assessment Program on a national basis for the incremental catchments associated with each reach in the NHD Plus Version 2 dataset (Preston and others, 2009; Michael Wieczorek, U.S. Geological Survey, written commun., June 11, 2011, and March 10, 2015).

For the Western Oregon SPARROW model, which is a regional model specific to suspended sediment and not requiring national datasets, we assessed a mix of data as potential explanatory variables (table 1).

Table 1. Potential explanatory variables evaluated in the Western Oregon SPARROW model.

\begin{tabular}{llll}
\hline \multicolumn{1}{c}{ Potential sediment sources } & Potential land-to-water delivery factors & & \multicolumn{1}{c}{ Network attributes } \\
\cline { 1 - 2 } Stream channel (reach length) & Mean annual precipitation & & Sediment removal in free-flowing streams \\
Area of Coast Range sedimentary lithologic province & Mean slope & & Sediment removal in impoundments \\
Area of Coast Range volcanic lithologic province & Wildfire disturbance & & \\
Area of Klamath Terrane & Percent forest land & \\
Area of Quaternary deposits & Percent agricultural land & \\
Area of Western Cascades lithologic province & Percent forest cover loss & \\
Area of High Cascades lithologic province & Mean canopy cover & \\
Area of NLCD forest land & Soil erodibility factor & \\
Area of NLCD scrub and grass land & & \\
Area of NLCD agricultural land & & \\
Area of NLCD developed land & & \\
\hline
\end{tabular}


These data represented land cover, geology, climate, soil properties, and hydrology. Most of these landscape properties were compiled by the National Water-Quality Assessment Program, but three datasets were compiled specifically for the modeling domain of this SPARROW application:

1. Six generalized lithologic provinces defined by O'Connor and others (2014) (fig. 1, table 2);

2. Areas disturbed by wildfire between 2000 and 2012 from the USGS Wildland Fire Decision Support System (U.S. Geological Survey, 2015b); and

3. Areas experiencing diminished forest cover between 2000 and 2014 from the Department of Geographical Sciences at the University of Maryland (Hansen and others, 2013).

The mapped areas of lithology, wildfire, and forest-cover loss were related to the hydrography in a manner similar to the national landscape attribute data.

\section{Model Calibration}

We chose the explanatory variables considered for the Western Oregon SPARROW model based on assumptions about the factors that control landscape sediment yield and the processes that affect sediment delivery to streams (table 1). Overall landscape sediment yield was evaluated using six different lithologic provinces as well as four different land cover classifications. Sediment delivery to streams was evaluated by considering landscape characteristics such as precipitation, slope, land cover, and soil properties. We also considered hydrologic network attributes that might increase suspended-sediment load (by bank erosion or bed-material comminution along a stream reach) as well as attributes that might decrease suspended-sediment load, such as reservoirs (through sediment settling) and free-flowing streams (through channel or floodplain deposition). The explanatory variables included in the final Western Oregon SPARROW model represented statistically significant geospatial variables. A one-sided significance level of 0.10 (based on a t-test) was applied to explanatory variables that could only relate to suspended-sediment loads in a positive manner. These variables included the lithology and land cover classifications (because only positive sediment yields were possible) and the sediment loss in impoundments and free-flowing streams (because of the way that SPARROW is configured to model these processes). However, for variables where the relation to suspended-sediment loads could be positive or negative (such as the land-to-water delivery factors), significance was judged with a two-sided significance level of 0.05 .

Table 2. Description of the lithologic provinces used as sources in the Western Oregon SPARROW model of suspended sediment.

[Share of modeling domain: Percentage of modeling domain that consists of each lithologic province]

\begin{tabular}{|c|c|c|}
\hline Lithologic province & $\begin{array}{l}\text { Share of } \\
\text { modeling } \\
\text { domain }\end{array}$ & Description \\
\hline Coast Range Sedimentary & 15 & Paleocene to Oligocene marine sandstone and siltstone. \\
\hline Coast Range Volcanics & 6.0 & $\begin{array}{l}\text { Paleocene to Eocene basalt and diabase in the Coast Range and } \\
\text { Miocene Columbia River Basalt Group in the northern part } \\
\text { of the model area. }\end{array}$ \\
\hline Klamath Terrane & 28 & $\begin{array}{l}\text { Tectonically accreted and uplifted Paleozoic and Mesozoic } \\
\text { rocks in southwestern Oregon and northwestern California. } \\
\text { Most are metamorphosed to some degree. }\end{array}$ \\
\hline Quaternary & 17 & $\begin{array}{l}\text { Unconsolidated Quaternary sediment within basins, valley } \\
\text { bottoms, glaciated areas, and coastal plains. }\end{array}$ \\
\hline Western Cascades & 22 & $\begin{array}{l}\text { Eocene to Pliocene volcanic rocks associated with early phases } \\
\text { of Cascade Range volcanism. }\end{array}$ \\
\hline High Cascades & 22 & $\begin{array}{l}\text { Quaternary basalts and andesites of the modern Cascade Range } \\
\text { volcanic arc. }\end{array}$ \\
\hline
\end{tabular}


Final model selection was based on the overall model fit by evaluating the yield $\mathrm{R}^{2}$, the root mean squared error (RMSE), and the residuals for spatial patterns. The yield $\mathrm{R}^{2}$ is the $\mathrm{R}^{2}$ value for the natural logarithm of yield and is a better measure of goodness of fit than the $\mathrm{R}^{2}$ of the calibration loads because it normalizes for the effect of contributing area, which commonly explains much of the variation in stream load. The RMSE, when multiplied by 100 , is approximately equal to one standard deviation percent error associated with the estimation for any single reach. The spatial patterns in model fit were evaluated by calculating and mapping the studentized residual for each calibration station and assessing spatial autocorrelation using the Moran's I statistic (Moran, 1950). The studentized residual is equal to the model residual (the difference between the natural logarithm of measured load and predicted load) divided by an estimate of its standard deviation.

The SPARROW model uses a nonlinear least squares regression to estimate model coefficients and provides a way to assess uncertainty in these estimated coefficients. Because of the nonlinear manner in which the estimated coefficients enter the model, this uncertainty is evaluated using a bootstrap resampling method (Schwarz and others, 2006) entailing repeated estimation of the model (200 times in this case) to obtain a range of values for each coefficient. A mean value (the nonparametric bootstrap estimate) is then estimated based on the results from this evaluation. The overall stability of the Western Oregon SPARROW model was evaluated by comparing the nonlinear regression estimates of the model coefficients to the nonparametric bootstrap estimates. The 90 percent confidence intervals for the estimated coefficients in the model were determined by using the standard errors and a $t$-distribution with $N-k$ degrees of freedom, where $N$ was the number of calibration stations and $k$ was the number of coefficients.

\section{Model Calibration Results and Predictions}

The final Western Oregon SPARROW model for suspended sediment included lithologic province, area affected by recent wildfire, and precipitation. Five of the six lithologic provinces were significantly correlated to suspended sediment (table 3). The High Cascades lithologic province was the single province that was not significant-indicating that areas of this geologic province contribute negligible amounts of suspended-sediment load. The statistically significant model coefficients for mean annual precipitation and the area of recent wildfire (fig. 2) also were positive, indicating that these attributes positively correlate with suspended-sediment loads. With lithologic province, precipitation, and area affected by wildfire all entered into the model, none of the other potential explanatory variables related to sediment sources, delivery to streams, and aquatic loss were statistically significant (table 3 ).

The final model explained about 64 percent of the variability in suspended-sediment yields with an RMSE of 0.737 (fig. 3, table 3). The nonlinear least squares regression estimates for most of the model terms generally matched the nonparametric bootstrap estimates (the exception was for wildfire disturbance, where the nonparametric bootstrap estimate was about 10 times greater than the nonlinear least squares regression estimate), but the 90 percent confidence intervals for most coefficients were large. A p-value of 0.79 for the Moran's I test showed that there was no significant spatial autocorrelation among the studentized residuals (fig. 4), but there was an overall pattern of model overprediction in the northern Oregon coastal drainages and the Willamette River Basin and underprediction in the southern Oregon coastal drainages and the Klamath River basin (table 4).

The final model enables predictions of both the incremental and total suspended-sediment load (and yield) for each of the 34,746 stream or river reaches in the modeling domain (fig. 5). The overall model results show that the northern Oregon coastal drainages had the highest suspended-sediment yields whereas the Klamath River Basin had the lowest (table 4). Quaternary deposits were, on average, the largest incremental contributor to the suspended sediment delivered to streams across the modeling domain and the Coast Range volcanic lithologic province was the smallest contributor (table 5). To evaluate suspended-sediment loads along individual streams and rivers, incremental suspended-sediment loads from each reach were cumulated down the hydrologic network. These load estimates were adjusted at each calibration station to match the measured suspended-sediment load, thereby providing more accurate estimates for all downstream reaches-figures 6 and 7 show this for the Umpqua and Rogue River Basins. The estimated suspended-sediment load at the 68 calibration stations used in the model ranged from 23.7 percent to 617 percent of the measured load, with an average value of 132 percent (see appendix A). The prediction results from the Western Oregon SPARROW model for each of the 34,734 NHD Plus Version 2 stream reaches included within the model domain can be accessed at http://dx.doi.org/10.3133/sir20165079. 
Table 3. Calibration results for the western Oregon SPARROW model of suspended sediment.

[A bbreviations: NLLS, non-linear least squares; $\mathrm{km}^{2}$, square kilometer; $\left(\mathrm{kg} / \mathrm{km}^{2}\right) / \mathrm{yr}$, kilogram per square kilometer per year; $(\mathrm{kg} / \mathrm{m}) / \mathrm{yr}, \mathrm{kilogram}$ per meter per year; m, meter; cm, centimeter; RMSE, root mean squared error; <, less than; -, not applicable]

\begin{tabular}{|c|c|c|c|c|c|c|c|}
\hline \multirow{2}{*}{ Parameter } & \multirow{2}{*}{$\begin{array}{l}\text { Model } \\
\text { coefficient } \\
\text { units }\end{array}$} & \multirow{2}{*}{$\begin{array}{c}\text { NLLS } \\
\text { estimate } \\
\text { of model } \\
\text { coefficient }\end{array}$} & \multirow{2}{*}{$\begin{array}{l}\text { Standard } \\
\text { error of } \\
\text { the model } \\
\text { coefficient }\end{array}$} & \multirow{2}{*}{$\begin{array}{l}\text { Probability } \\
\text { level } \\
\text { (p-value) }\end{array}$} & \multicolumn{2}{|c|}{$\begin{array}{l}\text { 90-percent confidence } \\
\text { interval for the model } \\
\text { coefficient }\end{array}$} & \multirow{2}{*}{$\begin{array}{c}\text { Nonparametric } \\
\text { bootstrap } \\
\text { estimate } \\
\text { of model } \\
\text { coefficient }\end{array}$} \\
\hline & & & & & Lower & Upper & \\
\hline \multicolumn{8}{|l|}{ Sediment sources } \\
\hline Coast Range Sedimentary ${ }^{1}\left(\mathrm{~km}^{2}\right)$ & $\left(\mathrm{kg} / \mathrm{km}^{2}\right) / \mathrm{yr}$ & 15,920 & 8,186 & 0.0564 & 6,243 & 31,840 & 17,566 \\
\hline Coast Range Volcanics ${ }^{2}\left(\mathrm{~km}^{2}\right)$ & $\left(\mathrm{kg} / \mathrm{km}^{2}\right) / \mathrm{yr}$ & 12,896 & 7,182 & 0.0775 & 0 & 25,793 & 13,135 \\
\hline Klamath Terrane ${ }^{3}\left(\mathrm{~km}^{2}\right)$ & $\left(\mathrm{kg} / \mathrm{km}^{2}\right) / \mathrm{yr}$ & 5,563 & 2,936 & 0.0628 & 0 & 11,127 & 5,044 \\
\hline Quaternary ${ }^{4}\left(\mathrm{~km}^{2}\right)$ & $\left(\mathrm{kg} / \mathrm{km}^{2}\right) / \mathrm{yr}$ & 37,263 & 8,556 & $<0.0001$ & 27,498 & 74,526 & 41,774 \\
\hline Western Cascades $^{5}\left(\mathrm{~km}^{2}\right)$ & $\left(\mathrm{kg} / \mathrm{km}^{2}\right) / \mathrm{yr}$ & 4,877 & 2,696 & 0.0754 & 681 & 9,753 & 5,564 \\
\hline High Cascades ${ }^{6,7}\left(\mathrm{~km}^{2}\right)$ & $\left(\mathrm{kg} / \mathrm{km}^{2}\right) / \mathrm{yr}$ & - & - & 0.5549 & - & - & - \\
\hline Reach Length $^{7}(\mathrm{~m})$ & $(\mathrm{kg} / \mathrm{m}) / \mathrm{yr}$ & - & - & 0.6932 & - & - & - \\
\hline \multicolumn{8}{|l|}{ Land-to-water delivery } \\
\hline Precipitation $^{8}(\mathrm{~cm})$ & - & 1.965 & 0.345 & $<0.0001$ & 1.269 & 2.56 & 1.925 \\
\hline Wildfire Disturbance ${ }^{9}\left(\mathrm{~km}^{2}\right)$ & - & 0.023 & 0.008 & 0.0067 & 0.008 & 2.97 & 0.235 \\
\hline Percent Forest Land ${ }^{7}$ & - & - & - & 0.1754 & - & - & - \\
\hline $\begin{array}{l}\text { Percent Forest Cover Loss } \\
\text { (not associated with wildfire } \\
\text { disturbance) })^{7}\end{array}$ & - & - & - & 0.4533 & - & - & - \\
\hline Percent Agricultural Land ${ }^{7}$ & - & - & - & 0.6800 & - & - & - \\
\hline Mean Canopy Cover ${ }^{7}$ (percent) & - & - & - & 0.1638 & - & - & - \\
\hline Soil Erodibility Factor ${ }^{7}$ & - & - & - & 0.4259 & - & - & - \\
\hline \multicolumn{8}{|l|}{ Aquatic loss } \\
\hline Free-flowing streams ${ }^{7}$ & - & - & - & - & - & - & - \\
\hline Impoundments $^{7}$ & - & - & - & - & - & - & - \\
\hline \multicolumn{8}{|l|}{ Model diagnostics } \\
\hline $\mathrm{R}^{2}$ of yield & & 0.641 & & & & & \\
\hline RMSE & & 0.737 & & & & & \\
\hline Number of observations & & 68 & & & & & \\
\hline
\end{tabular}

${ }^{1}$ Area of Coast Range sedimentary lithologic province.

${ }^{2}$ Area of Coast Range volcanic lithologic province.

${ }^{3}$ Area of Klamath Terrane.

${ }^{4}$ Area of Quaternary deposits.

${ }^{5}$ Area of Western Cascades lithologic province.

${ }^{6}$ Area of High Cascades lithologic province.

${ }^{7}$ Not inlcluded in the final model.

${ }^{8}$ Natural log of mean annual precipitation (1981-2010).

${ }^{9}$ Percentage of catchment disturbed by wildfire between 2000 and 2012. 


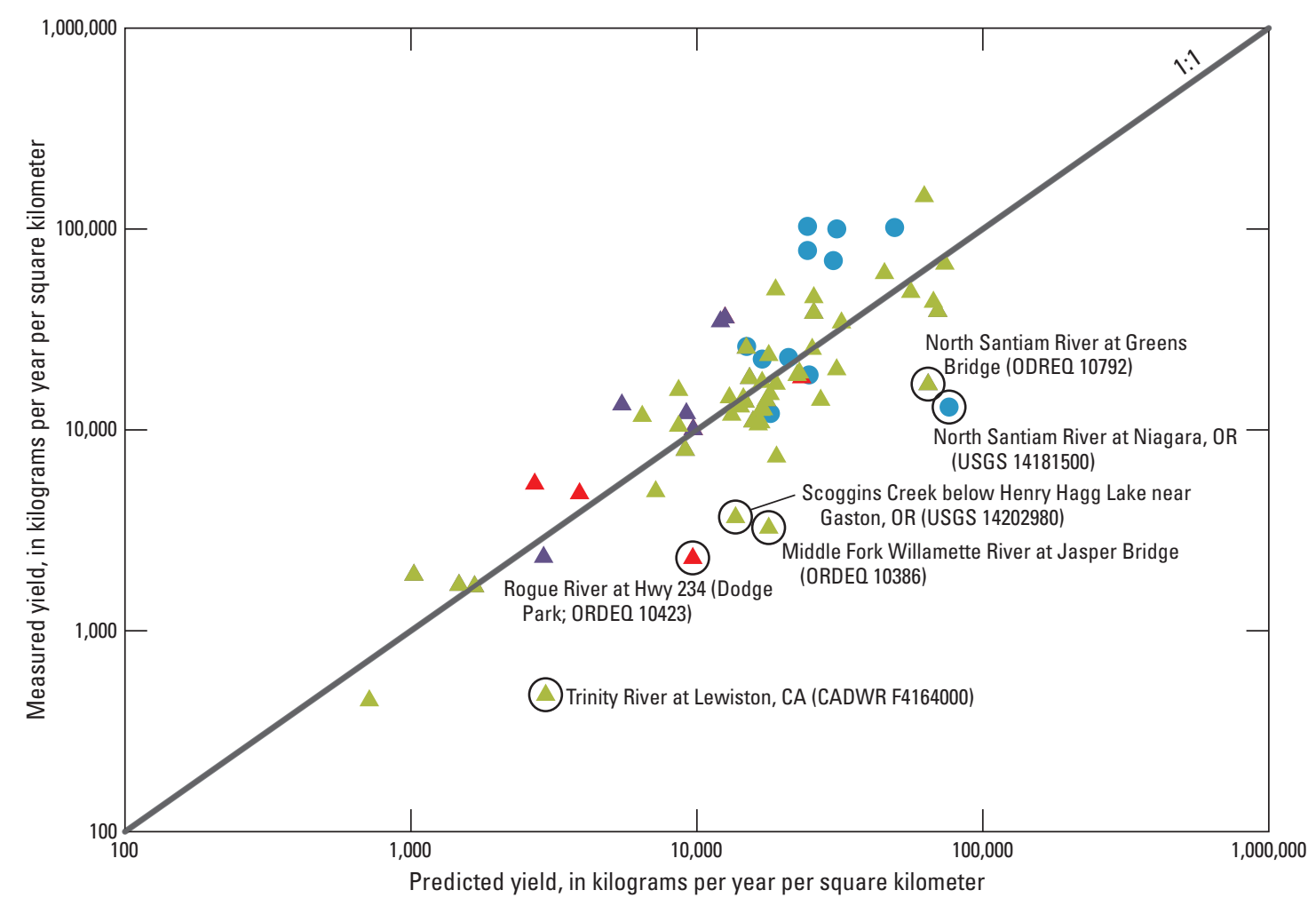

EXPLANATION

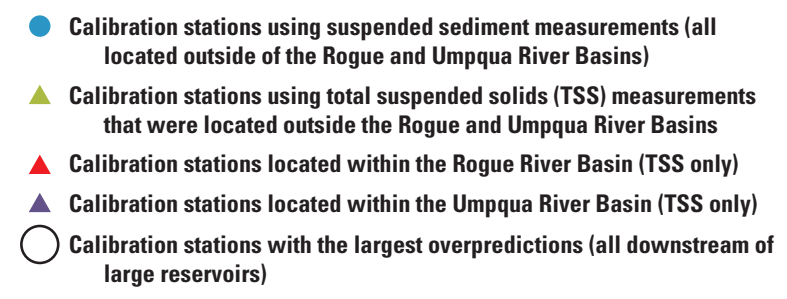

Figure 3. Comparison of the measured and predicted yields from the Western Oregon SPARROW model of suspended sediment.

Table 4. Model calibration results, median incremental yields, and flow-weighted concentrations predicted for each six-digit Hydrological Unit Code watershed by the Western Oregon SPARROW model of suspended sediment.

[M edian studentized residual: Values less than zero indicate overprediction while values greater than zero indicate underprediction. M edian incremental yield: Incremental yield is equal to the incremental load divided by the incremental catchment area, where the incremental load is the load generated exclusively within an National Hydrography Dataset (NHD) catchment. Median flow-weighted concentration: Mean annual flow-weighted suspended-sediment concentration for each reach was calculated by dividing the total predicted suspended-sediment load (the load contributed by all upstream areas) by the estimated the mean annual streamflow included with the NHD Plus Version 2.

Abbreviations: $(\mathrm{kg} / \mathrm{ha}) / \mathrm{yr}$, kilogram per hectare per year; $\mathrm{mg} / \mathrm{L}$; milligram per liter]

\begin{tabular}{|c|c|c|c|c|}
\hline $\begin{array}{c}\text { Six-digit } \\
\text { Hydrological Unit Code } \\
\text { watershed }\end{array}$ & $\begin{array}{l}\text { Number of } \\
\text { calibration } \\
\text { stations }\end{array}$ & $\begin{array}{l}\text { Median } \\
\text { studentized } \\
\text { residual }\end{array}$ & $\begin{array}{c}\text { Median } \\
\text { incremental yield } \\
{[(\mathrm{kg} / \mathrm{ha}) / \mathrm{yr}]}\end{array}$ & $\begin{array}{l}\text { Median flow- } \\
\text { weighted } \\
\text { concentration } \\
(\mathrm{mg} / \mathrm{L})\end{array}$ \\
\hline Northern Oregon Coastal Drainages & 8 & -0.17 & 475 & 20 \\
\hline Southern Oregon Coastal Drainages & 11 & 0.43 & 128 & 11 \\
\hline Willamette River Basin & 43 & -0.11 & 221 & 13 \\
\hline Smith River Basin & 0 & na & 230 & 12 \\
\hline Klamath River Basin & 6 & 0.10 & 52.9 & 7.7 \\
\hline
\end{tabular}



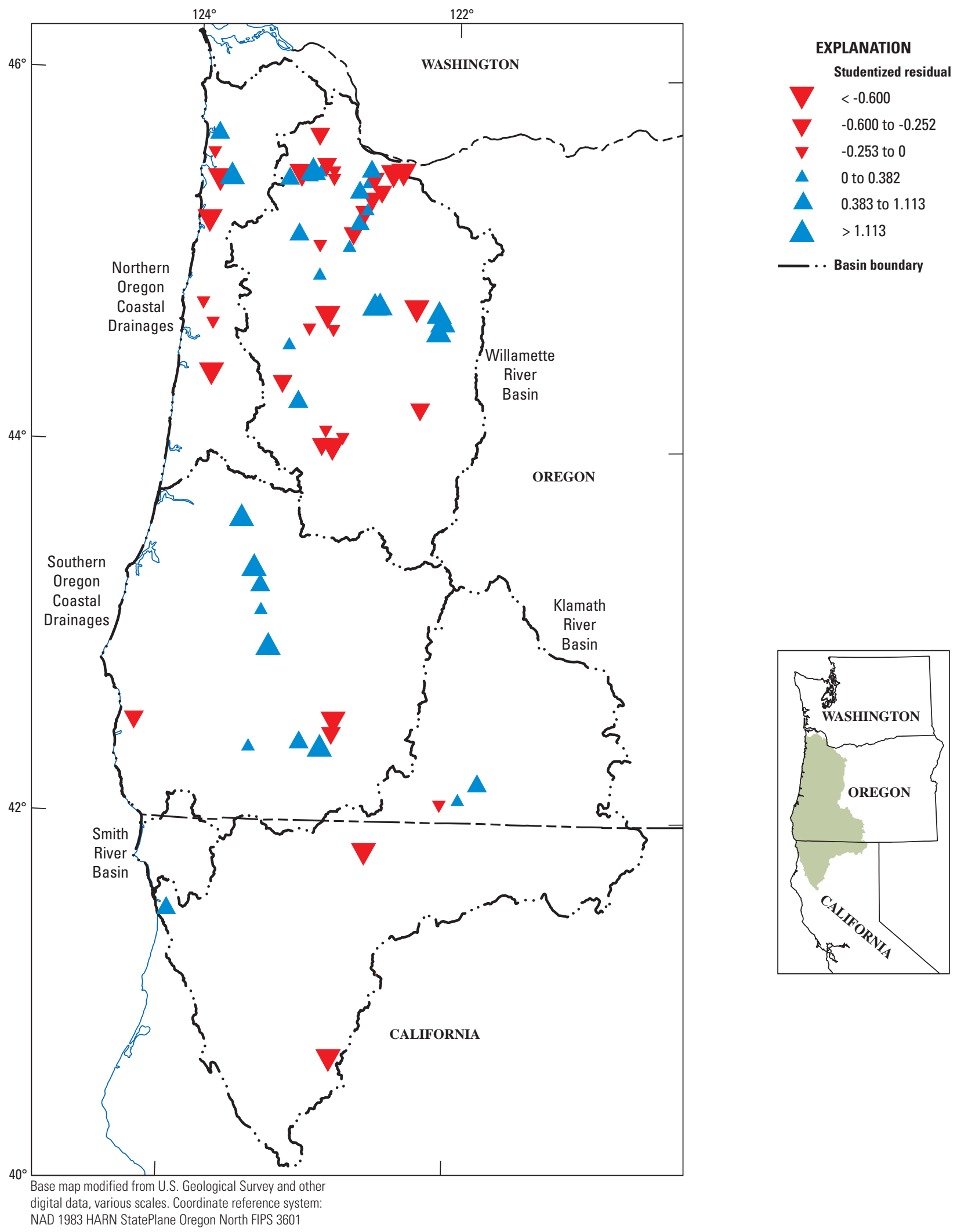

Figure 4. Studentized residuals for the Western Oregon SPARROW model of suspended sediment. 


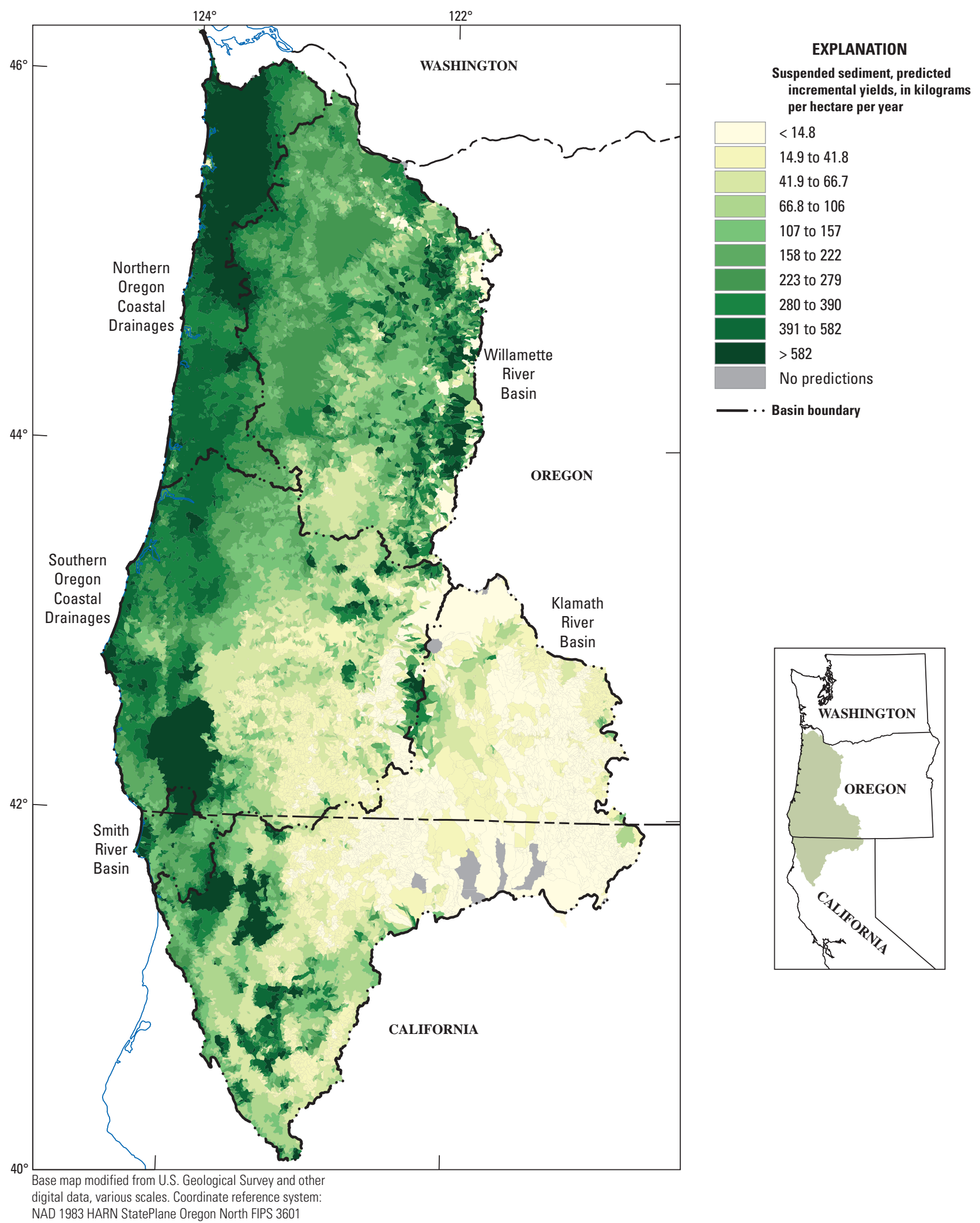

Figure 5. Incremental yields predicted by the Western Oregon SPARROW model of suspended sediment. 


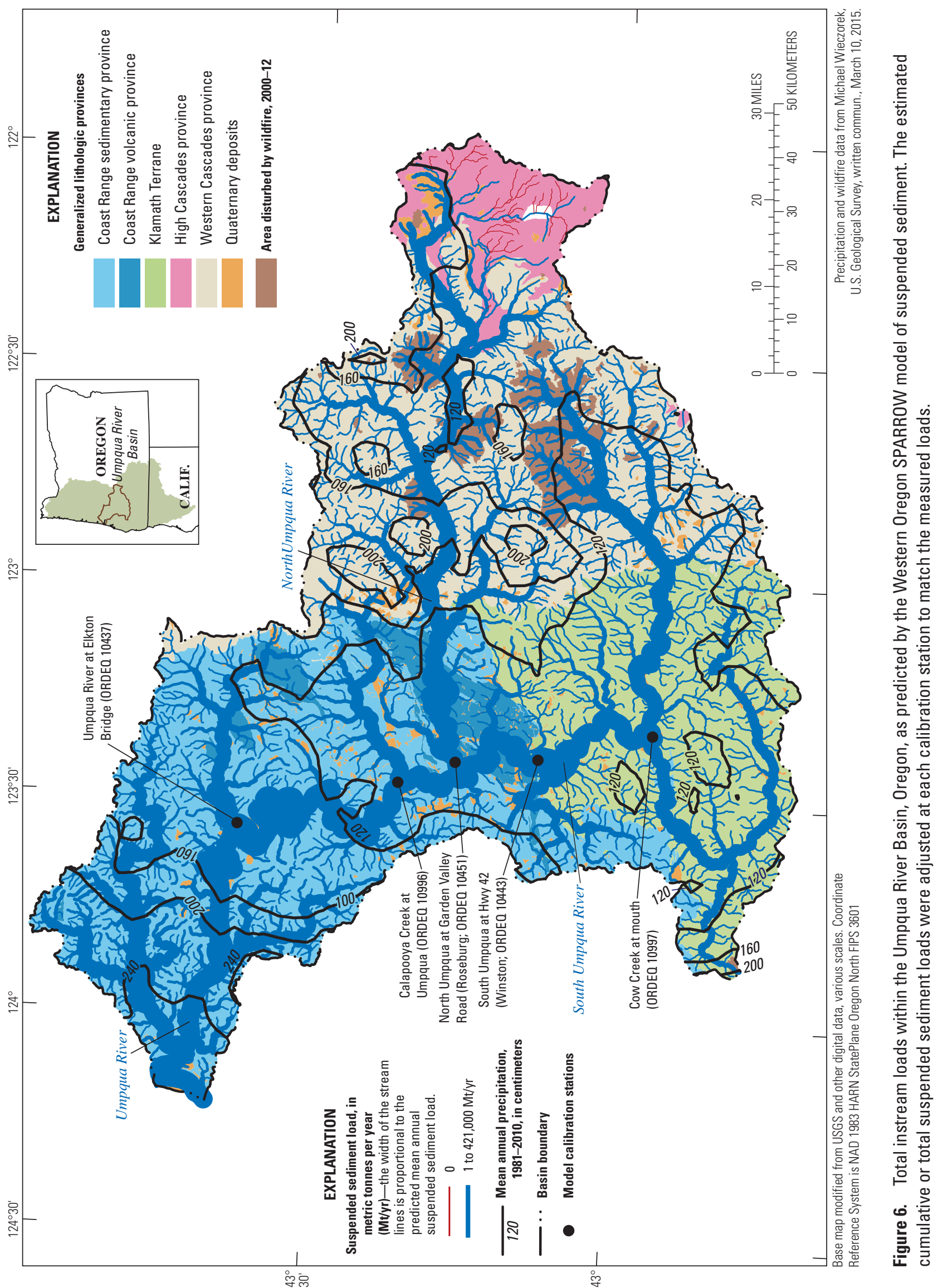




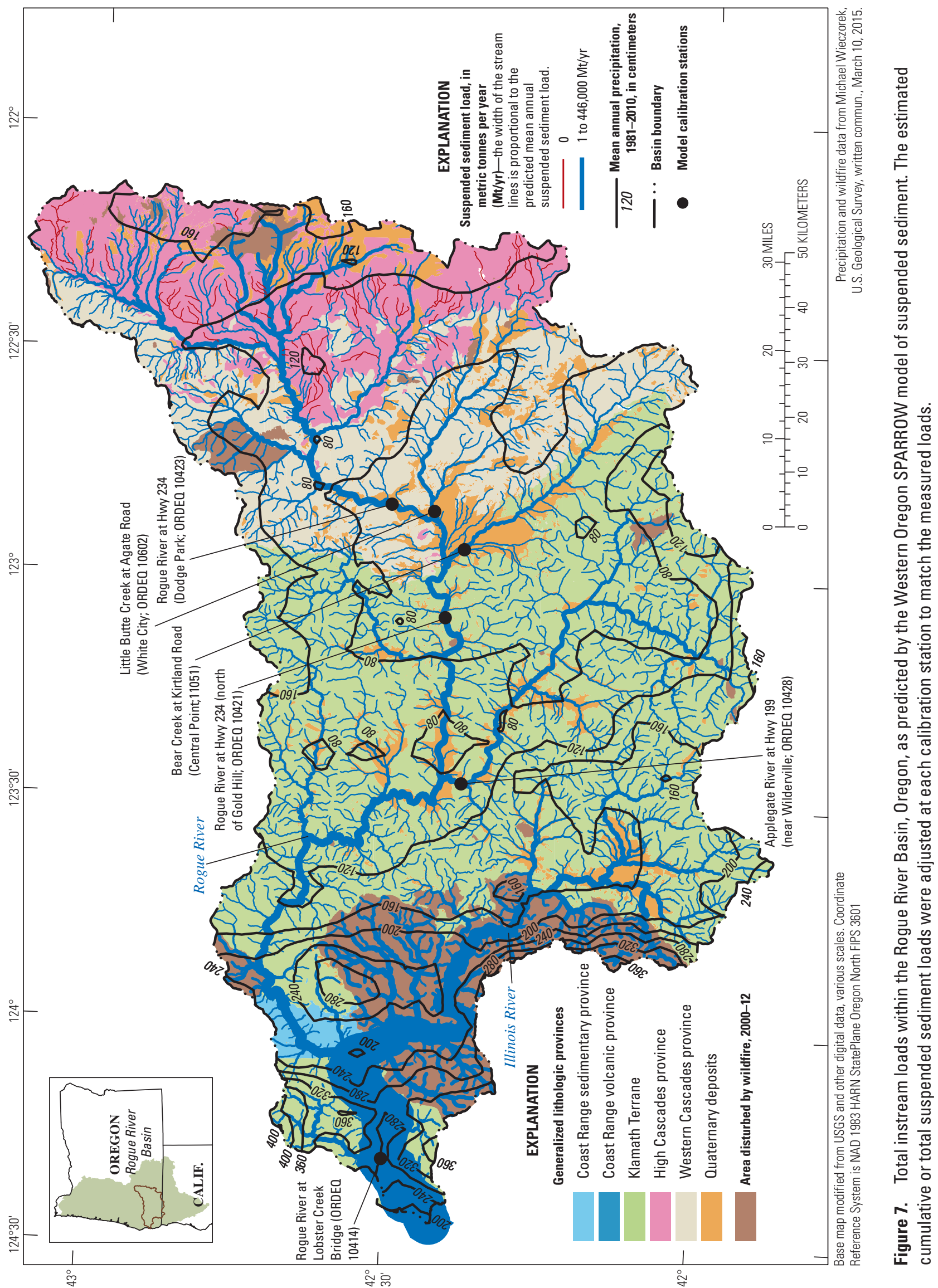


Table 5. Summary statistics for incremental loads predicted by the Western Oregon SPARROW model of suspended sediment.

[M ean source share: The percentage of the total amount of suspendedsediment load delivered to streams that was contributed by each lithologic province. Share of modeling domain: The percentage of the total amount of suspended-sediment load delivered to streams that was contributed by each lithologic province]

\begin{tabular}{lcc}
\hline \multicolumn{1}{c}{ Lithologic province } & $\begin{array}{c}\text { Mean } \\
\text { source } \\
\text { share }\end{array}$ & $\begin{array}{c}\text { Share of } \\
\text { modeling } \\
\text { domain }\end{array}$ \\
\hline Coast Range sedimentary & 15 & 15 \\
Coast Range volcanics ${ }^{1}$ & 5.3 & 6.0 \\
Klamath Terrane & 30 & 28 \\
Quaternary & 32 & 17 \\
Western Cascades & 18 & 22 \\
\hline${ }^{1}$ Area of Coast Range Sedimentary lithologic province. & \\
${ }^{2}$ Area of Coast Range Volcanic lithologic province. & \\
${ }^{3}$ Area of Klamath Terrane lithologic province. \\
${ }^{4}$ Area of Quaternary deposits. \\
${ }^{5}$ Area of Western Cascades lithologic province.
\end{tabular}

\section{Discussion}

\section{Model Formulation}

The final Western Oregon SPARROW model for suspended-sediment included explanatory variables representing geology, precipitation, and areas of recent wildfire. These variables combined to provide the best fit as judged by the RMSE, explaining about 64 percent of the variance in the measured suspended yields (table 3 ).

In contrast to the other SPARROW suspended-sediment applications for the Chesapeake Bay (Brakehill and others, 2010) and the continental U.S. (Schwarz, 2008), land-use and slope are not in the final Western Oregon SPARROW model. Some land-use attributes were significant predictors in the absence of the lithologic province variables, but the scrubland-grassland class - accounting for 26 percent of the model area - was not significant, thereby resulting in an unrealistically large area of the domain having no predicted suspended-sediment load. Mean catchment slope is a logical explanatory variable for suspended-sediment yield and has been incorporated into many empirical models of suspended-sediment yield. For example, the U.S. Department of Agriculture's Universal Soil Loss Equation (USLE) incorporates slope in the calculation of the slope-steepness factor (Wischmeier and Smith, 1978). In the Western Oregon SPARROW model, however, slope offered less explanatory power than precipitation. Slope was indeed significant and positively correlated with suspended-sediment load when included in the model without mean precipitation, but it was not significant when mean precipitation also was included in the model. In addition, the model with precipitation provided an overall better fit than the model with slope, indicating that precipitation had more explanatory power than catchment slope. These interactions partly owe to the positive but weak spatial correlation between mean annual precipitation and mean catchment slope across the modeling domain $(r=0.50$, p-value $<0.00001$; Daly and others, 2008).

Other differences in the Western Oregon SPARROW model compared to the two other sediment applications were the absence of a source term representing reach length, the absence of an in-stream loss term, and the absence of an impoundment loss term. Suspended-sediment loads were positively correlated with reach length in both of the previous SPARROW suspended-sediment applications and were attributed to bank erosion and remobilization of bed sediments (Schwarz, 2008; Brakebill and others, 2010). Reach-scale gains in suspended-sediment load within the Western Oregon SPARROW modeling domain likely owe to these processes in addition to comminution of bedload into smaller particles (O'Connor and others, 2014). The absence of such gains in the Western Oregon SPARROW model may indicate covariance with other terms, such as lithologic province, or that sediment deposition in marginal channel areas or floodplains compensates for length-dependent sources. For example, synoptic suspended-sediment transport measurements during 2005-06 high flows in the Sprague River of the upper Klamath River Basin indicated that about 35 percent of the suspended load was deposited along the channel and floodplains (O'Connor and others, 2015). Impoundments such as reservoirs, lakes, and ponds typically reduce downstream transport by trapping suspended sediment. The effect of impoundments can be evaluated by the SPARROW model (Schwarz and others, 2006), but including these features in the Western Oregon SPARROW model did not significantly improve model fit — even when multiple reservoir classifications and different modeling scenarios were evaluated. However, the largest model overpredictions were downstream of large impoundments, perhaps indicating that the current SPARROW structure does not adequately assess the effect of impoundments.

\section{Model Bias}

An evident bias not accounted for in the model calibration relates to the type and frequency of sediment measurements used at the calibration stations. The measured suspended-sediment loads at the 57 calibrations stations measuring TSS (in contrast to suspended sediment) were, on average, 12 percent greater than the predicted suspended-sediment load. In contrast, the measured suspended-sediment loads at the 11 calibration stations following the standard protocols for suspended-sediment measurement (Guy, 1969) were, on average, 89 percent greater than the predicted suspended-sediment loads. This indicates that the final Western Oregon SPARROW model may substantially underestimate actual suspended-sediment loads 
if the suspended-sediment measurements are indeed better measurements of the actual suspended-sediment concentration and annual sediment loads than typical TSS measurements. This bias probably arises from two factors. One is the negative bias associated with the TSS measurement subsampling protocol, which can result in low suspended-sediment values from a given sample (Gray and others, 2000). Another factor is that most of the suspended-sediment and TSS measurements used to estimate the calibration loads for the Western Oregon SPARROW model were collected during routine sampling and may not represent the infrequent, high-flow periods when most of the annual suspended-sediment load is transported (Wolman and Miller, 1960).

An example of the importance of high-flow measurements in the model area is provided by Sobieszczyk and others (2015), who determined mean annual suspended-sediment yield for water years 2012-14 for the Wilson and Trask River Basins in the Oregon Coast Range (table 6). Their sediment-load estimates relied on many measurements at high flow; for example, 83 percent of the measurements used in the regression for the Wilson River were collected at streamflow within the upper quartile of all values measured between 1983 and 2012. The 2012 yields based on measured TSS loads and model-estimated, suspended-sediment loads for the same locations on the Wilson and Trask Rivers were respectively 55 and 23 percent lower than the mean annual suspended-sediment yields for 2012-14 that were estimated by Sobieszczyk and others (2015). This was consistent with the overall regional bias associated with difference between TSS and suspended-sediment measurement protocols.

\section{Role of Geology}

Lithologic province was a strong predictor of suspendedsediment yield, and the coefficients for the different provinces matched expectations. Unconsolidated Quaternary deposits, mainly consisting of valley alluvium, glacial deposits, and sandy coastal plains, had the highest model coefficient (and lowest significance level) (table 3). These deposits are typically erodible and accessible to streams. The Coast Range sedimentary and volcanic provinces also had relatively high model coefficients, indicating that they yielded large amounts of suspended sediment compared to the Western Cascades and Klamath terrane provinces. The Coast Range sedimentary and volcanic provinces cover large areas and correspond with steep slopes and strongly dissected topography; consequently, these areas are some of the greatest producers of sediment yield in the study area (fig. 5). The sedimentary rocks, in particular, rapidly break down by abrasion during transport and contribute to suspended load in the modeled area (O'Connor and others, 2014). The Western Cascades and Klamath terrane provinces had the lowest model coefficients, which was consistent with tumbler experiments showing that these rocks had lower abrasion rates than the rocks in the other lithologic provinces (O'Connor and others, 2014).

One lithologic province, the High Cascades, did not significantly correlate with suspended-sediment load. Although this meant that the High Cascades do not yield any suspended-sediment load in the model, this result is consistent with the distinct terrain and hydrologic behavior associated with this lithologic province (O'Connor and others, 2003; fig. 8). These young volcanic rocks are the hardest of any within the study domain (O'Connor and others, 2014), are drained by poorly integrated stream systems, and have less relief than the other lithologic provinces - all factors that inhibit the production and downstream transport of suspended sediment (O'Connor and others, 2003; Jefferson and others, 2010).

\section{Sediment Delivery to Streams}

The Western Oregon SPARROW model showed a positive correlation between suspended-sediment yield and two catchment attributes - mean annual precipitation and the area of recent wildfire disturbance. The positive correlation between suspended sediment and mean annual precipitation is consistent with recent regional studies; for example, Andrews and Antweiler (2012) empirically estimated sediment flux for coastal California, showing that mean annual sediment yield was proportional to mean annual precipitation. Few studies examining the relation between fire and sediment yield have been conducted specifically in the study area, but De La Fuente and others (2014) found sediment deposits in the Klamath River Basin resulting from highly sediment-laden floods after large storms rained on recently burned forests. Multiple studies elsewhere in western North America have also indicated increased sediment yield following fire, both as a consequence of removing stabilizing vegetation cover and by increasing hillslope water runoff (for example, Cannon and others, 2008; Berg and Azuma, 2010; Moody and Martin, 2009; Moody and others, 2013). 
Discussion

17

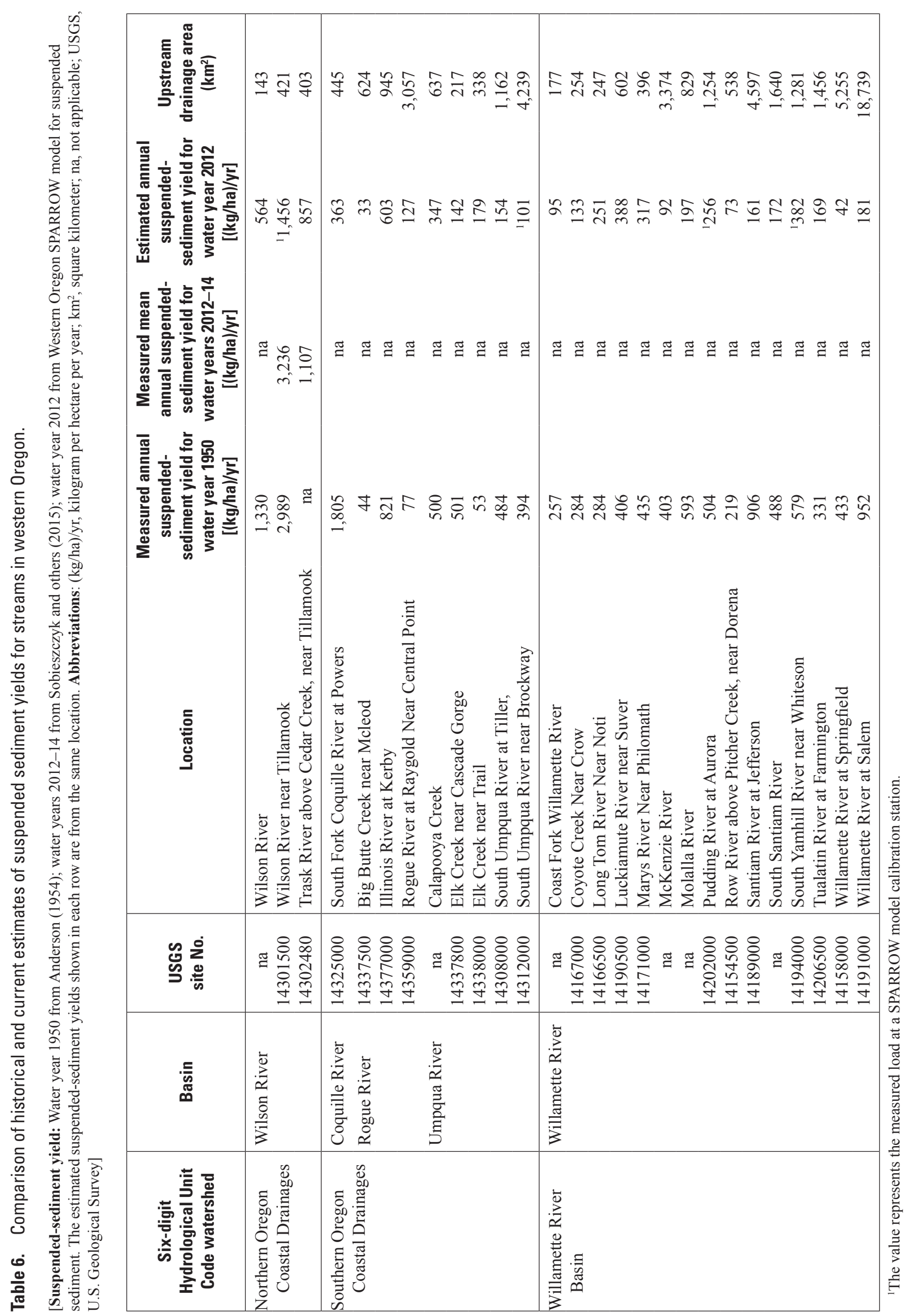




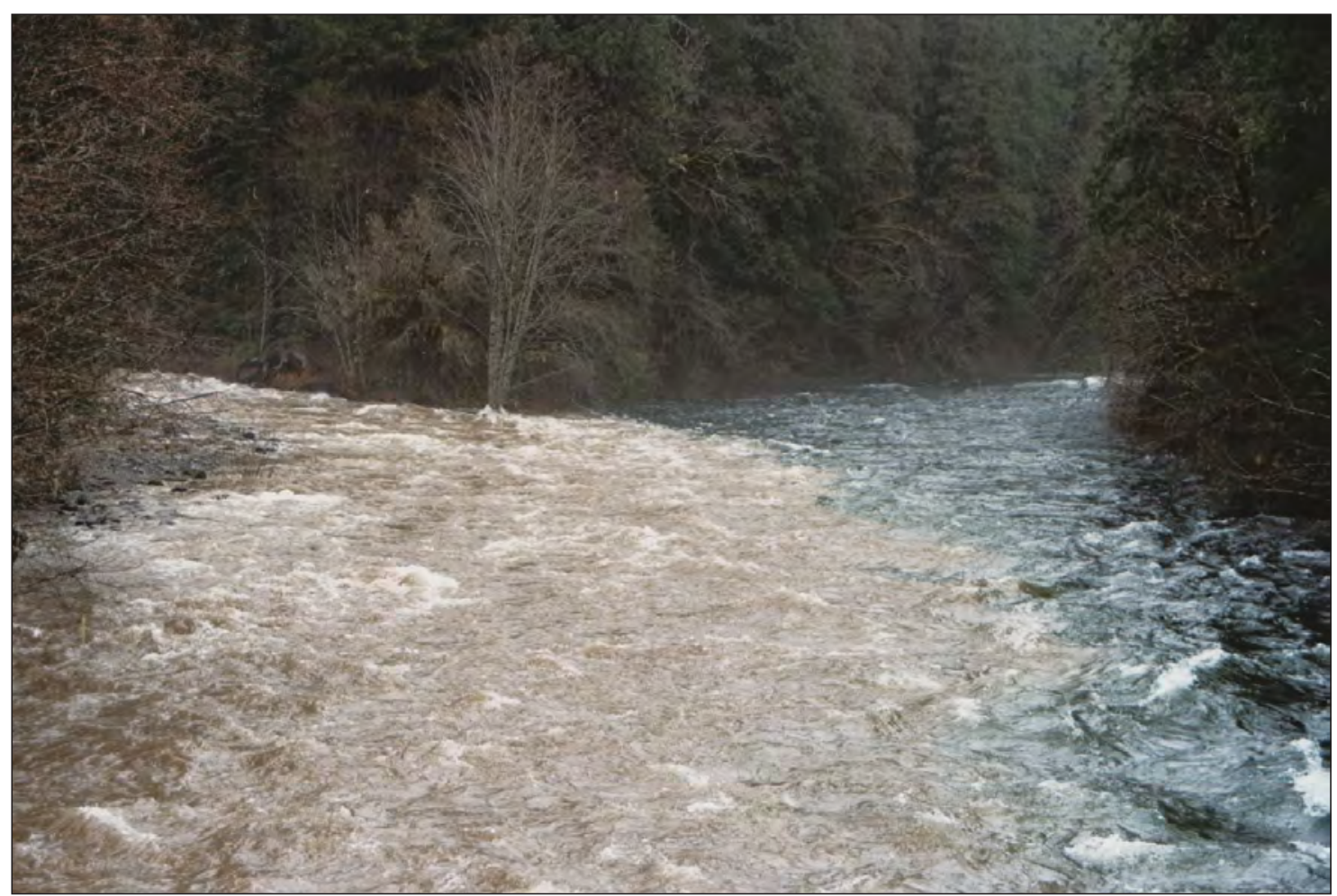

Figure 8. Confluence of turbid Deer Creek and the much clearer Mackenzie River (latitude 44.239, longitude -122.058) during high flow on January 29, 2003, western Oregon. Sixty-seven percent of the 59 square kilometer $\left(\mathrm{km}^{2}\right)$ drainage for Deer Creek lies within the Western Cascades lithologic province and 32 percent lies within the High Cascades. By contrast, 76 percent of the $527 \mathrm{~km}^{2}$ draining to the Mackenzie River at its confluence with Deer Creek lies within the High Cascades lithologic province, which provides very little sediment, and 21 percent is made up of Quaternary sediment. (Photograph by Jim O'Connor, U.S. Geological Survey).

\section{Spatial Patterns}

The overall patterns of suspended-sediment yield for western Oregon (fig. 5) correspond with the lithologic provinces (fig. 1), but also follow regional precipitation patterns and fire history (fig. 2). The northern Oregon coastal drainages had the highest predicted median incremental suspended-sediment yield (476 kilograms per hectare per year $[(\mathrm{kg} / \mathrm{ha}) / \mathrm{yr}])$ and flow-weighted concentration $(20 \mathrm{mg} / \mathrm{L})$ whereas the Klamath River Basin had the lowest $(52.9(\mathrm{~kg} / \mathrm{ha}) / \mathrm{yr} ; 7.5 \mathrm{mg} / \mathrm{L})$. These results owe to the combined influence of the erodible Coast Range rock types compared to the Klamath terrane, as well as the greater amount of precipitation in the northern Oregon Coast Range. Some regions of the Klamath terrane recently affected by wildfire, however, had high predicted, suspended-sediment yields - particularly the Illinois River basin in the Rogue River watershed (fig. 7). High suspended-sediment yields also were predicted for parts of the Willamette Valley (chiefly because of the extensive Quaternary alluvial deposits) and for parts of the Western Cascades (particularly in the wet area in northern Oregon). The eastern parts of the southern Oregon coastal drainages and the Klamath River Basin had the lowest predicted suspended-sediment yields, owing to the absence of erodible lithologic provinces and low precipitation.

Some of the factors influencing the spatial patterns of the model predictions across the modeling domain are evident in the substantial differences in the mean annual suspended-sediment loads discharged from the Umpqua and Rogue Rivers Basins (figs. 6 and 7). These river basins are broadly similar; they have adjacent headwaters in the Cascade Range and flow through the Coast Range before entering the Pacific Ocean in southwestern Oregon. The Rogue River Basin drains $13,390 \mathrm{~km}^{2}$, slightly larger than the $12,103 \mathrm{~km}^{2}$ of the Umpqua River Basin. Despite its smaller size, however, the Umpqua River has a predicted average annual suspended-sediment load of 421,000 metric tons per year $(\mathrm{Mt} / \mathrm{yr})$ at its mouth, which is 68 percent greater than the $250,000 \mathrm{Mt} / \mathrm{yr}$ for the Rogue River. This difference owes mostly to the different lithologic provinces in the lower reaches of each basin. The lower Umpqua River drains mostly Coast Range sedimentary rocks, which produce substantial 
amounts of suspended sediment, thereby greatly increasing downstream sediment loads (fig. 6). In contrast, the lower Rogue River flows mostly through the Klamath lithologic province, which produces much less suspended sediment. The predicted difference between the Umpqua and Rogue Rivers would be even greater if not for the substantial suspended-sediment contribution of the Illinois River, which contributes 77 percent of the total suspended-sediment load in the Rogue River despite only accounting for 19 percent of the total drainage area. The high predicted yield of the Illinois River $(1,162(\mathrm{~kg} / \mathrm{ha}) / \mathrm{yr})$ is partly due to more precipitation but chiefly results from the extensive area burned by a 2002 wildfire in that watershed.

\section{Relation to Historical Conditions}

The Western Oregon SPARROW model predicts suspended-sediment loads and yield for mean annual current conditions. Specifically, the calibration data are normalized and detrended to represent 2012 sediment loads and yields for average annual hydrologic conditions. Such loads and yields may not be representative, however, of previous or long-term, suspended-sediment transport or landscape erosion rates. For example, the measured mean annual TSS yields (1983-2012) at the five calibration stations within the Umpqua River Basin were only 2.9-11 percent of the measured mean annual suspended sediment yields for the same stations during 1956-1973 (Curtiss, 1975), indicating a remarkable decline in suspended-sediment loads (table 7). Although we could not completely reproduce Curtiss' results because not all the historical data were available, we did estimate mean annual suspended-sediment yields using the Fluxmaster program (no detrending) for the 1961-73 period at two stations (1431000, Cow Creek near Riddle, and 14312000, South Umpqua River near Canyonville; Fluxmaster was not able to estimate the mean annual load for the entire 1956-73 period for unknown reasons, but was able to estimate the load for the 1961-73 period). Our estimates were 83 percent and 79 percent of those estimated by Curtiss for Cow Creek and the South Umpqua River, respectively, using the same suspended-sediment measurements and streamflow available to Curtiss (1975). These estimates were slightly lower than what Curtiss originally calculated using a different approach to estimate annual loads, but still much higher than the detrended, more-recent values determined in this study.

The reasons for this decrease in suspended-sediment load within the Umpqua River Basin are uncertain, but may relate to multiple factors. The 1964 flood (during the period of the Curtiss [1975] measurements) produced exceptional sediment loads during the flood as well as causing many landslides and debris flows that continued to deliver sediment to regional rivers (Wallick and others, 2011). The Curtiss (1975) period of measurements was during extensive timber harvest in the region. A study of three small watersheds within the Alsea River basin in the Oregon Coast Range during the 1960s showed that increases in suspended-sediment yields were associated with forest road building, clear-cut logging, and slash burning (Brown and Krygier, 1971). Similar forest practices existed throughout western Oregon Coast Range during that time as well (Brown and Krygier,

Table 7. Comparison of historical and current measurements of suspended-sediment yields for streams in the Umpqua River Basin, Oregon.

\begin{tabular}{|c|c|c|c|c|c|}
\hline Stream name & $\begin{array}{l}\text { Historical } \\
\text { USGS station }\end{array}$ & $\begin{array}{c}\text { Mean annual } \\
\text { suspended- } \\
\text { sediment yield } \\
\text { for water years } \\
1956-73 \\
{[(\mathrm{~kg} / \mathrm{ha}) / \mathrm{yr}]}\end{array}$ & $\begin{array}{c}\text { Mean annual } \\
\text { suspended- } \\
\text { sediment yield } \\
\text { for water years } \\
1961-73 \\
{[(\mathrm{~kg} / \mathrm{ha}) / \mathrm{yr}]}\end{array}$ & $\begin{array}{l}\text { Western Oregon } \\
\text { SPARROW model } \\
\text { calibration station }\end{array}$ & $\begin{array}{c}\text { Mean annual } \\
\text { TSS yield } \\
\text { for water years } \\
1983-2012 \\
{[(\mathrm{~kg} / \mathrm{ha}) / \mathrm{yr}]}\end{array}$ \\
\hline Umpqua River & 14321000 & 3,293 & na & OR DEQ 10437 & 363 \\
\hline South Umpqua River & 14312000 & 3,503 & 2,771 & OR DEQ 10443 & 101 \\
\hline North Umpqua River & 14319500 & 2,067 & na & OR DEQ 10451 & 121 \\
\hline Calapooya Creek & 14320700 & 3,117 & na & OR DEQ 10996 & 347 \\
\hline Cow Creek & 14310000 & 2,872 & 2,395 & OR DEQ 10997 & 134 \\
\hline
\end{tabular}




\section{A Spatially Explicit Suspended-Sediment Load Model for Western Oregon}

1971). Peak timber production in Douglas County (which includes most of the Umpqua River Basin) occurred during the 1950s and 1960s, but production from public lands decreased substantially after 1988 when management emphasis shifted from production to habitat protection. Timber production during 1988 was 397 million board feet, but average production between 1991 and 2000 averaged only 29 million board feet, and dropped to 6.7 million board feet between 2001 and 2003 (Wallick and others, 2011). In addition, the Oregon Forest Practices Act of 1971 strengthened existing rules and created new requirements for reducing erosion, preventing runoff, and protecting water resources (Oregon Department of Forestry, 2015). Preliminary results from a recent study by Richardson (2015) suggest that mean sedimentation in an Oregon Coast Range lake decreased after implementation of the Oregon Forest Practices Act. However, some of the difference between the historical and recent suspended-sediment yields may be due to different measurement protocols between the 1956-73 standard suspended-sediment measurements (sampled by the USGS) and the more recent TSS measurements (sampled by Oregon Department of Environmental Quality), as noted in section, "Model Bias."

Another comparison with historical data is provided by Anderson's (1954) analysis of suspended-sediment yields for 26 sites in western Oregon. The 2012 suspended-sediment yields estimated by the Western Oregon SPARROW model were, on average, about 62 percent of the measured 1950 values (table 6). This difference also could owe to changes in forest practices, the TSS sampling bias, or from comparing average annual loads to records from a single year.

The predicted suspended-sediment yields from the Western Oregon SPARROW model range from $52.9(\mathrm{~kg} / \mathrm{ha}) / \mathrm{yr}$ for the Klamath River Basin to $476(\mathrm{~kg} / \mathrm{ha}) / \mathrm{yr}$ for the northern Oregon coastal drainages. These yields equate to solid rock erosion rates of $0.002-0.019 \mathrm{~mm} / \mathrm{yr}$, assuming a rock density of 2,600 kilograms per cubic meter (Manger, 1963). These values are less than 20 percent of the $0.1-0.3 \mathrm{~mm} / \mathrm{yr}$ long-term (approximately 4,000-year) erosion rates estimated for the Oregon Coast Range between $43^{\circ} \mathrm{N}$ and $46^{\circ} \mathrm{N}$ latitude from cosmogenic Beryllium-10 $\left({ }^{10} \mathrm{Be}\right)$ concentrations in fluvial sediments (Balco and others, 2013). In addition, the 4,000-year long-term erosion rates are consistent with rock uplift rates estimated from even older uplifted marine and river terraces in the central Oregon Coast Range (Personius, 1995).
The lower erosion rates associated with the suspendedsediment yields predicted by the Western Oregon SPARROW model compared to long-term erosion rates likely result from a number of factors.

1. The erosion rates may be affected by the measurement biases noted in "Model Bias", which may result in substantially lower estimated suspended-sediment loads. However, this alone would not fully account for the fivefold discrepancy with the long-term rates.

2. The erosion rates do not include the contribution from bedload, for which yields range from 0.05 to $0.13 \mathrm{~mm} / \mathrm{yr}$ for the Coast Range sedimentary and Klamath terrane lithologic provinces, respectively (O'Connor and others, 2014). Even adding this component, however, results in total sediment loads that are likely less than the cosmogenically determined rates.

3. The erosion rates do not include the load from dissolved material, which may account for 60 percent of the total mass loss from the Coast Range (Dietrich and Dunne, 1978) and one-third of the total mass loss in a small western Cascade Range watershed (Swanson and others, 1982). We used Fluxmaster to estimate the mean annual loads of total suspended and total dissolved solids for the 1981-2000 period at three pairs of nearly co-located Coast Range water-quality stations operated by the Oregon DEQ and the USGS (table 8). These estimates showed that total dissolved solids contributed between 42.5 and 60.6 percent of the total solids loads at those stations, where total solids were equal to total dissolved solids plus total suspended solids.

4. The 1983-2012 suspended load measurements forming the basis for the SPARROW analysis may not represent millennial time-scale averages, possibly because of a low number of exceptional flows or mass movements during this period as well as changes in land use and sediment retention behind dams.

5. Naturally occurring episodic fire could be a major long-term process affecting sediment loads in parts of western Oregon and northwestern California. The final model indicates elevated sediment loads from fire-affected lands and, consequently, fire suppression related to forest management may have reduced sediment flux during the period of this study. 
Table 8. Comparison of total suspended solids, total dissolved solids, and total solids for streams in the Oregon Coast Range.

[Total suspended solid and total dissolved solids load for water years 1981-2000 were estimated using the Fluxmaster program. A bbreviations: km², square kilometer; Mt/yr, metric ton (1,000 kilograms) per year; OR DEQ, Oregon Department of Environmental Quality; USGS; U.S. Geological Survey]

\begin{tabular}{|c|c|c|c|c|c|c|c|c|}
\hline \multirow[b]{2}{*}{ Stream name } & \multicolumn{3}{|c|}{ OR DEO water-quality stations } & \multicolumn{3}{|c|}{ USGS water-quality stations } & \multirow[b]{2}{*}{$\begin{array}{c}\text { Mean } \\
\text { annual total } \\
\text { solids load for } \\
\text { water years } \\
\text { 1981-2000 } \\
\text { (Mt/yr) }\end{array}$} & \multirow[b]{2}{*}{$\begin{array}{c}\text { Dissolved } \\
\text { solids as a } \\
\text { percentage } \\
\text { of total } \\
\text { solids }\end{array}$} \\
\hline & $\begin{array}{l}\text { Western Oregon } \\
\text { SPARROW } \\
\text { model calbration } \\
\text { station }\end{array}$ & $\begin{array}{l}\text { Upstream } \\
\text { drainge area } \\
\qquad\left(\mathrm{km}^{2}\right)\end{array}$ & $\begin{array}{c}\text { Mean } \\
\text { annual total } \\
\text { suspended } \\
\text { solids load for } \\
\text { water years } \\
\text { 11981-2000 } \\
\text { (Mt/yr) }\end{array}$ & $\begin{array}{c}\text { USGS } \\
\text { water-quality } \\
\text { station } \\
\text { with total } \\
\text { dissolved } \\
\text { solids data }\end{array}$ & $\begin{array}{l}\text { Upstream } \\
\text { drainage } \\
\text { area }\left(\mathbf{k m}^{2}\right)\end{array}$ & $\begin{array}{c}\text { Mean } \\
\text { annual total } \\
\text { dissolved } \\
\text { solids load for } \\
\text { water years } \\
\text { 11981-2000 } \\
\text { (Mt/yr) }\end{array}$ & & \\
\hline Umpqua River & OR DEQ 10437 & 9,520 & 386,318 & 14321000 & 9,428 & 365,618 & 751,936 & 48.6 \\
\hline South Umpqua River & OR DEQ 10443 & 4,239 & 104,159 & 14312260 & 4,603 & 160,154 & 264,313 & 60.6 \\
\hline Nehalem River & OR DEQ 11856 & 1,854 & 136,671 & 14301000 & 1,708 & 100,932 & 237,603 & 42.5 \\
\hline
\end{tabular}

${ }^{1}$ Estimated using the Fluxmaster program.

\section{Application of Model Results}

Our results provide broad-scale information on the sources and factors associated with suspended-sediment transport in western Oregon. Such results may support regional sediment management objectives and priorities. They also could possibly support water-quality management for individual watersheds by providing an understanding of the key factors controlling suspended-sediment yield and transport. However, this analysis is of a very coarse nature, with significant biases and uncertainties that most likely underestimate sediment loads. Moreover, the regionally estimated coefficients are not likely to be the best predictors of suspended-sediment yield for a specific watershed. Such limitations could be overcome by intensive local analyses such as that of Sobieszczyk and others (2015) for the Wilson and Trask Rivers.

\section{Summary and Conclusions}

The Western Oregon SPARROW model provides predictions of recent (2012) suspended-sediment transport loads and yields for western Oregon and northwestern California. This empirical model used 68 calibration stations distributed throughout the modeling domain, and explained 64 percent of the variance in the measured suspendedsediment yields. The significant explanatory variables were lithologic province, precipitation, and area disturbed by recent wildfire. Other landscape characteristics (land cover, slope, forest cover loss, canopy cover, and soil erodibility) also were considered, but were either not significant predictors of sediment transport, strongly correlated with another predictor variable, or not as strong a predictor variable as those ultimately selected for the final model. Suspended-sediment yields were greatest in the northern Oregon coastal drainages, which are mostly underlain by erodible sedimentary rocks and where precipitation is high. The spatial variation in geology and precipitation explained most of the distinct patterns in suspended-sediment yields across the modeling domain. Recent suspended-sediment yields predicted by the Western Oregon SPARROW model were much lower than historical yields measured in the Umpqua River Basin as well as regional long-term erosion rates determined by cosmogenic nuclides and uplifted terraces. Some of this discrepancy may owe to measurement biases (and changes in field collection and laboratory analytical methods), but it also likely indicates that suspended-sediment yields are variable and respond to changes in climate, vegetation, and land-use. Such sensitivity may have implications for the spatial and temporal distributions of aquatic and riparian habitats.

\section{Acknowledgments}

We would like to thank Michael Wieczorek (U.S. Geological Survey) for compiling some of the catchment attribute datasets used in this study, Denise Argue (U.S. Geological Survey) for compiling the water-quality data, Krista Jones (U.S. Geological Survey) for her input on the report, and Joseph Mangano (U.S. Geological Survey) for helping produce the report graphics. 


\section{A Spatially Explicit Suspended-Sediment Load Model for Western Oregon}

\section{References Cited}

Alexander, R.B., Smith, R.A., Schwarz, G.E., Boyer, E.W., Nolan, J.V., and Brakebill, J.W., 2008, Differences in phosphorus and nitrogen delivery to the Gulf of Mexico from the Mississippi River Basin: Environmental Science and Technology, v. 42, no. 3, p. 822-830.

Andrews Experimental Forest, 2015, Stream chemistry concentrations and fluxes using proportional sampling in the Andrews Experimental Forest, 1968 to present: H.J. Andrews Experimental Forest Web page, accessed June 5, 2015, at http://andrewsforest.oregonstate.edu/data/ abstract.cfm?dbcode $=$ CF002\& topnav $=97$.

Andrews, E.D., and Antweiler, R.C., 2013, Sediment fluxes from California Coastal Rivers-The influences of climate, geology, and topography: Journal of Geology, v. 120, no. 4, p. 349-366.

Anderson, H.W., 1954, Suspended sediment discharge as related to streamflow, topography, soil, and land use: Transactions of the American Geophysical Union, v. 35, no. 2, p. 268-281.

Ator, S.W., Brakebill, J.W., and Blomquist, J.D., 2011, Sources, fate, and transport of nitrogen and phosphorus in the Chesapeake Bay watershed-An empirical model: U.S. Geological Survey Scientific Investigations Report 2011-5167, 27 p. [Also available at http://pubs.usgs.gov/ $\operatorname{sir} / 2011 / 5167 /$.

Balco, G., Finnegan, N., Gendaszek, A., Stone, J.O.H., and Thompson, N., 2013, Erosional response to northwardpropagating crustal thickening in the Coastal Ranges of the U.S. Pacific Northwest: American Journal of Science, v. 313 , p. $790-806$.

Berg, N.H., and Azuma, D.L., 2010, Bare soil and rill formation following wildfires, fuel reduction treatments, and pine plantations in the southern Sierra Nevada, California, USA: International Journal of Wildland Fire, v. 19 , p. $478-489$.

Brakebill, J.W., Ator, S.W., and Schwarz, G.E., 2010, Sources of suspended-sediment flux in streams of the Chesapeake Bay watershed-A regional application of the SPARROW model: Journal of the American Water Resources Association, v. 46, no. 4, p. 757-776.

Brown, G.W., and Krygier, J.T., 1971, Clear-cut logging and sediment production in the Oregon Coast Range: Water Resources Research, v. 7, no. 5, p. 1,189-1,198.
Brown, J.B., Sprague, L.A., and Dupree, J.A., 2011, Nutrient sources and transport in the Missouri River Basin, with emphasis on the effects of irrigation and reservoirs: Journal of the American Water Resources Association, v. 47, no. 5, p. $1,034-1,060$.

Cannon, S.H., Gartner, J.E., Wilson, R., Bowers, J., and Laber, J., 2011, Storm rainfall conditions for floods and debris flows from recently burned areas in southwestern Colorado and southern California: Geomorphology, v. 96, no. 3-4, p. $250-269$.

California Department of Water Resources, 2015, Data Library: California Department of Water Resources Web page, accessed March 9, 2015, at http://www.water.ca.gov/ waterdatalibrary/waterquality/index.cfm.

Curtiss, D.A, 1975, Sediment yields of streams in the Umpqua River Basin, Oregon: U.S. Geological Survey Open-File Report, 1 plate with text.

Daly, C., Halbleib, M., Smith, J.I., Gibson, W.P., Doggett, M.K., Taylor, G.H., Curtis, J., and Pasteris, P.P., 2008, Physiographically sensitive mapping of climatological temperature and precipitation across the conterminous United States: International Journal of Climatology, v. 28, p. 2,031-2,064.

De La Fuente, J.A., Bachmann, S., Mai, C., Mikulovsky, R., Mondry, Z.J., Rust, B., and Young, D., 2014, Erosion and sedimentation from the Bagley Fire, eastern Klamath Mountains, Northern CA: American Geophysical Union, Fall Meeting 2014, abstract \#H51I-0726, accessed June 24, 2015, at http://adsabs.harvard.edu/abs/2014AGUFM. H51I0726D.

Dietrich,W.E., and Dunne, T., 1978, Sediment budget for a small catchment in mountainous terrain: Zeitschrift für Geomorphologie, Supplementband, v. 29, p. 191-206.

Elliott, A.H, Alexander, R.B., Schwarz, G.E., Shankar, Ude, Sukias, J.P.S., and McBride, G.B., 2005, Estimation of nutrient sources and transport for New Zealand using the hybrid mechanistic-statistical model SPARROW: Journal of Hydrology (NZ), v. 44, no. 1, p. 1-27.

Garcia, A.M., Hoos, A.B., and Terziotti, Sylvia, 2011, A regional modeling framework of phosphorus sources and transport in streams of the southeastern United States: Journal of the American Water Resources Association, v. 47, no. 5 , p. 991-1,010.

Gray, J.R., Glysson, G.D., Turcios, L.M., and Schwarz, S.E., 2000, Comparability of suspended sediment concentration and total suspended solids data: U.S. Geological Survey Water-Resources Investigations Report 00-4191, 14 p. 
Griffiths, W.H., and Walton, B.D., 1978, The effects of sedimentation on the aquatic biota: Edmonton, Alberta, Alberta Oil Sands Environmental Research Program Report 35, 86 p.

Guy, H.P., 1969, Laboratory theory and methods for sediment analysis: U.S. Geological Survey Techniques of WaterResources Investigations, book 5, chapter C1, 56 p., http:// pubs.usgs.gov/twri/twri5c1/html/pdf.html.

Hansen, M.C., Potopov, P.V., Moore, R., Hancher, M., Turubanova, S.A., Tyukavina, A., Thau, D., Stehman, S.V., Goetz, S.J., Loveland, T.R., Kommareddy, A., Egorov, A., Chini, L, Justice, C.O., Townshend, J.R.G., 2013, Highresolution global maps of 21 st-century forest cover change: Science, v. 342, p. 850-853, accessed March 20, 2015, at http://earthenginepartners.appspot.com/science-2013global-forest.

Hoos, A.B., and McMahon, Gerard, 2009, Spatial analysis of instream nitrogen loads and factors controlling nitrogen delivery to streams in the southeastern United States using Spatially Referenced Regressions on Watershed Attributes (SPARROW) and regional classification frameworks: Hydrological Processes, v. 22, no. 16, p. 2,275-2,294.

Horizon Systems, 2013, NHDPlusV2Data: Horizon Systems database, accessed March 18, 2013, at http://www.horizonsystems.com/nhdplus/.

Jefferson, A., Grant, G.E., Lewis, S.L., and Lancaster, S.T., 2010, Coevolution of hydrology and topography on a basalt landscape in the Oregon Cascade Range, USA: Earth Surface Processes and Landforms, v. 35, p. 803-816, doi: 10.1002/esp.1976.

Jin, S., Yang, L., Danielson, P., Homer, C., Fry, J., and Xian, G., 2013, A comprehensive change detection method for updating the National Land Cover Database to circa 2011: Remote Sensing of Environment, v. 132, p. 159-175.

Johnson, H.M., Black, R.W., and Wise, D.R., 2013, Estimation of total nitrogen and total phosphorus in streams of the Middle Columbia River Basin (Oregon, Washington, and Idaho) using SPARROW models, with emphasis on the Yakima River Basin, Washington: U.S. Geological Survey Scientific Investigations Report 2013-5199, 28 p., http:// dx.doi.org/10.3133/sir20135199.

Manger, G.E., 1963, Porosity and bulk density of sedimentary rocks: U.S. Geological Survey Bulletin 1144-E, 55 p.

Moody, J.A., and Martin, D.A., 2009, Synthesis of sediment yields after wildland fire in different rainfall regimes in the western United States: International Journal of Wildland Fire, v. 18, p. 96-115.
Moody, J.A., Shakesby, R.A., Robichaud, P.R., Cannon, S.H., and Martin, D.A., 2013, Current research issues related to post-wildfire runoff and erosion processes: Earth Science Reviews, v. 122, p. 10-37.

Moore, R.B., Johnston, C.M, Smith, R.A., and Milstead, Bryan, 2011, Source and delivery of nutrients to receiving waters in the northeastern and mid-Atlantic regions of the United States: Journal of the American Water Resources Association, v. 47, no. 5, p. 965-990.

Moran, P.A.P, 1950, Notes on continuous stochastic phenomena: Biometrika, v. 37, no. 1/2, p. 17-23.

Morris, G.L., Fan J., 1998, Reservoir sedimentation handbook - Design and management of dams, reservoirs, and watersheds for sustainable use: New York, McGrawHill, 805 p.

O’Connor, J.E. Grant, G.E., and Haluska, T.L., 2003, Overview of geology, hydrology, geomorphology, and sediment budget of the Deschutes River basin, Oregon, in, O’Connor, J.E., and Grant, G.E., eds., A peculiar riverGeology, geomorphology, and hydrology of the Deschutes River, Oregon: American Geophysical Union Water Science and Application Series, no. 7, p. 7-29.

O’Connor, J.E., Mangano, J.F., Anderson, S.W., Wallick, J.R., Jones, K.L., and Keith, M.K., 2014, Geologic and physiographic controls on bed-material yield, transport, and channel morphology for alluvial and bedrock rivers, western Oregon: Geological Society of America Bulletin, v. 126, no. $3 / 4$, p. $377-397$.

O'Connor, J.E., McDowell, P.F., Lind, Pollyanna, Rasmussen, C.G., and Keith, M.K., 2015, Geomorphology and floodplain vegetation of the Sprague and lower Sycan Rivers, Klamath Basin, Oregon: U.S. Geological Survey Scientific Investigations Report 2014-5223, 122 p., 1 pl., http:// dx.doi.org/10.3133/sir20145223.

Oregon Department of Environmental Quality, 2015a, Total maximum daily loads (TMDLs) program: Oregon Department of Environmental Quality Web page, accessed March 18, 2015, at http://www.deq.state.or.us/wq/tmdls/ tmdls.htm.

Oregon Department of Environmental Quality, 2015b, Laboratory Analytical Storage and Retrieval Web Application: Oregon Department of Environmental Quality Web page, accessed March 9, 2015, at http://deq12.deq. state.or.us/lasar2/.

Oregon Department of Forestry, 2015, Oregon Forest Practices Act-Adaptable and informed by sound science: Salem, Oregon, Oregon Department of Forestry, 4 p., accessed August 24, 2015, at http://oregonforests.org/sites/default/ files/publications/pdf/ODF_timeline_WEB2.pdf. 
Oregon Department of Water Resources, 2015, Historical streamflow and lake level data: Oregon Department of Water Resources Web page, accessed March 31, 2015, at http://apps.wrd.state.or.us/apps/sw/hydro_report/.

Personius, S.F., 1995, Late Quaternary stream incision and uplift in the forearc of the Cascadia subduction zone, western Oregon: Journal of Geophysical Research-Solid Earth, v. 100, B10, p. 20,193-20,210.

Preston, S.D., Alexander, R.B., Woodside, M.D., and Hamilton, P.A., 2009, SPARROW modeling-Enhancing understanding of the Nation's water quality: U.S. Geological Survey Fact Sheet 2009-3019, 6 p.

Rebich, R.A., Houston, N.A., Mize, S.V., Pearson, D.K., Ging, P.B., and Hornig, C.E., 2011, Sources and delivery of nutrients to the northwestern Gulf of Mexico from streams in the south-central United States: Journal of the American Water Resources Association, v. 47, no. 5, p. 1,061-1,086.

Richardson, Kris, 2015, The role of forest harvest practices and extreme events on the sedimentation of an Oregon Coast Range lake: Portland, Oregon, Abstract in Program of the American Fisheries Society 2015 annual meeting (August 16-20), accessed August 25, 2015, at https://afs. confex.com/afs/ 2015/webprogram/Paper20725.html.

Robertson, D.M., and Saad, D.A., 2011, Nutrient inputs to the Laurentian Great Lakes by source and watershed estimated using SPARROW watershed models: Journal of the American Water Resources Association, v. 47, no. 5, p. 1,011-1,033.

Schwarz, G.E., Hoos, A.B., Alexander, R.B., and Smith, R.A., 2006, The SPARROW surface water-quality model-Theory, applications and user documentation: U.S. Geological Survey Techniques and Methods, book 6, chap. B3, 248 p. [Also available on CD-ROM and at http://pubs. usgs.gov/tm/2006/tm6b3/.]

Schwarz, G.E., 2008, A Preliminary SPARROW model of suspended sediment for the conterminous United States: U.S. Geological Survey Open-File Report 2008-1205, 8 p., http://pubs.usgs.gov/of/2008/1205.

Seaber, P.R., Kapinos, F.P., and Knapp, G.L., 1987, Hydrologic unit maps: U.S. Geological Survey WaterSupply Paper 2294, 63 p.

Simley, J.D., and Carswell Jr., W.J., 2009, The National Map-Hydrography: U.S. Geological Survey Fact Sheet 2009-3054, 4 p.
Smith, R.A., Schwarz, G.E., and Alexander, A.B., 1997, Regional interpretation of water-quality monitoring data: Water Resources Research, v. 33, no. 12, p. 2,781-2,798.

Sobieszczyk, Steven, Bragg, H.M., and Uhrich, M.A., 2015, Water-quality conditions and suspended-sediment transport in the Wilson and Trask Rivers, northwestern Oregon, water years 2012-14: U.S. Geological Survey Scientific Investigations Report 2015-5109, 32 p., http://dx.doi. org/10.3133/sir20155109.

Swanson, F.J., Fredriksen, R.L., and McCorison, F.M., 1982, Material transfer in a western Oregon forested watershed, in Edmonds, R.L., ed., Analysis of coniferous forest ecosystems in the western United States: Stroudsburg, Pennsylvania, Hutchison Ross Publishing, p. 233-266.

U.S. Geological Survey, 2015a, Water-data site information for the nation: U.S. Geological Survey National Water Information System, accessed March 9, 2015, at http:// waterdata.usgs.gov/nwis/si.

U.S. Geological Survey, 2015b, Wildland fire decision support system-Data downloads: U.S. Geological Survey Wildland Fire Decision Support System Web page, accessed March 10, 2015, at http://wfdss.usgs.gov/wfdss/WFDSS_Data_ Downloads.shtml.

Wischmeier, W.H., and Smith, D.D., 1978, Predicting rainfall erosion losses - A guide to conservation planning: U.S. Department of Agriculture Agricultural Handbook No. 537, $58 \mathrm{p}$.

Wallick, J.R., O’Connor, J.E., Anderson, S., Keith, M., Cannon, C., and Risley, J.C., 2011, Channel change and bed-material transport in the Umpqua River basin, Oregon: U.S. Geological Survey Scientific Investigations Report 2011-5041, 112 p., http://pubs.usgs.gov/sir/2011/5041/.

Wise, D.R., and Johnson, H.M., 2013, Application of the SPARROW model to assess surface-water nutrient conditions and sources in the United States Pacific Northwest: U.S. Geological Survey Scientific Investigations Report 2013-5103, 32 p., http://pubs.usgs.gov/ $\operatorname{sir} / 2013 / 5103 /$.

Wolman, M.G., and Miller, J.P., 1960, Magnitude and frequency of forces in geomorphic processes: Journal of Geology, v. 68, no. 1, p. 54-74. 


\section{Appendix A. Summary of Calibration Data for the Suspended Sediment Sparrow Model Developed for Western Oregon and Northwestern California}

Appendix A (Excel ${ }^{\circledR}$ file) is available for download at http://dx.doi.org/10.3133/sir20165079. 

Publishing support provided by the U.S. Geological Survey Science Publishing Network, Tacoma Publishing Service Center

For more information concerning the research in this report, contact the Director, Oregon Water Science Center

U.S. Geological Survey

2130 SW 5th Avenue

Portland, Oregon 97201

http://or.water.usgs.gov 
